\title{
Impact of Recent Energy \\ Legislation on the Aluminum Industry
}

\author{
E. Edelson \\ J. G. Emery \\ W. J. Hopp \\ A. L. Kretz
}

June 1981

Prepared for the U.S. Department of Energy Assistant Secretary for Environmental Protection, Safety, and Emergency Preparedness Washington, D.C. 20545 under Contract DE-AC06-76RLO 1830

DOE Project Manager: T. S. Needels

Pacific Northwest Laboratory Operated for the U.S. Department of Energy by Battelle Memorial Institute 


\title{
NOTICE
}

This report was prepared as an account of work sponsored by the United States Government. Neither the United States nor the Department of Energy, nor any of their employees, nor any of their contractors, subcontractors, or their employees, makes any warranty, express or implied, or assumes any legal liability or responsibility for the accuracy. completeness or usefulness of any information, apparatus, product or process disclosed, or represents that its use would not infringe privately owned rights.

The views, opinions and conclusions contained in this report are those of the contractor and do not necessarily represent those of the United States Government or the United States Department of Energy.

PACIFIC NORTHWEST LABORATORY

operated by

BATTELLE

for the

UNITED STATES DEPARTMENT OF ENERGY

Under Contract DE-AC06-76RLO 1830

\author{
Printed in the United States of America \\ Available from \\ National Technical Information Service \\ United States Department of Commerce \\ 5285 Port Royal Road \\ Springfield, Virginia 22151
}

Price: Printed Copy s

$\because$ Microfiche $\$ 3.00$

\begin{tabular}{cc} 
•Pages & Selling Price \\
\hline $001-025$ & $\$ 4.00$ \\
$026-050$ & $\$ 4.50$ \\
$051-075$ & $\$ 5.25$ \\
$076-100$ & $\$ 6.00$ \\
$101-125$ & $\$ 6.50$ \\
$126-150$ & $\$ 7.25$ \\
$151-175$ & $\$ 8.00$ \\
$176-200$ & $\$ 9.00$ \\
$201-225$ & $\$ 9.25$ \\
$226-250$ & $\$ 9.50$ \\
$251-275$ & $\$ 10.75$ \\
$276-300$ & $\$ 11.00$
\end{tabular}


IMPACT OF RECENT ENERGY LEGISLATION

ON THE ALUMINUM INDUSTRY

E. Edelson

J. G. Emery

W. J. Hopp

A. L. Kretz

June 1981

Prepared for the U.S. Department of Energy under Contract DE-AC06-76RLO-1830

Pacific Northwest Laboratory

Richland, Washington 99352 


\section{ACKNOWLEDGMENTS}

The work reported here was conducted under the direction of and with funding from the U.S. Department of Energy, Office of Environmental Assessments, Technology Assessments Division. The authors wish to acknowledge the support of the Division and the guidance of the DOE project monitors, Dr. Arnold J. Goldberg and Theodore Needels, under contract DE-AC06-76RL0-1830. 


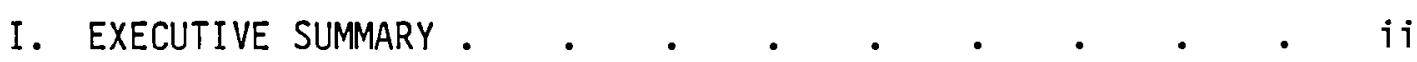

II. INTRODUCTION

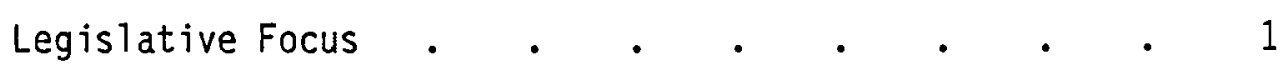

III. TECHNOLOGY OF THE ALUMINUM INDUSTRY.$\quad \cdot \quad \cdot \quad \cdot \quad \cdot 5$

The Reduction Process . . . . . . . . 5

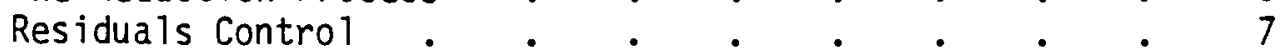

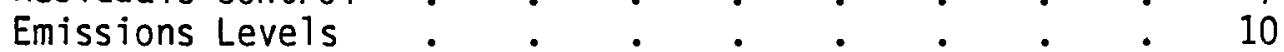

IV. THE ALUMINUM INDUSTRY AND ITS ROLE IN THE PACIFIC NORTHWEST 17

The Role of the DSIs in Power Planning . . • . 22

V. THE NORTHWEST POWER ACT.$\quad$.

Provisions of the Act . . . . . . . 27

Power Rates Under the Act . . . . . . 28

VI. THE IMPACT OF THE POWER ACT ON THE NORTHWEST ALUMINUM

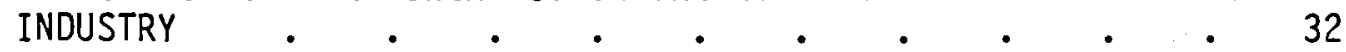

Competitive Effects . . . . . . . . . . 32

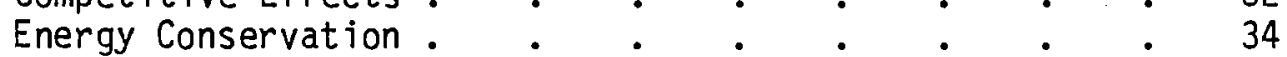

Primary Pot Aluminum Plant $: \quad \cdot \quad \cdot \quad \cdot \quad \cdot \quad \cdot \quad 36$

Conservation Potential . . . . . . . . . 40

Residuals From Aluminum Production : $: \quad \cdot \quad \cdot \quad \cdot{ }^{\circ}$

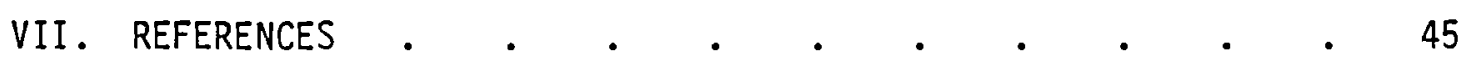




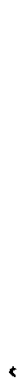

.

, 


\section{EXECUTIVE SUMMARY}

The primary objective of this research was to determine to what extent recent energy legislation would have a significant impact on the domestic aluminum smelting industry. The focus was on the industry's ability to remain competitive in world markets; its ability to meet present and future environmental requirements; and the effect of these requirements on energy conservation incentives, conservation techniques likely to be employed, and the relationship between energy conservation and environmental control.

This project was part of a multi-laboratory effort directed at major energy-using industries.

The Pacific Northwest Power Planning and Conservation Act (the Northwest Power Act) was analyzed for its effects on the Pacific Northwest aluminum smelting industry. Topics discussed in the context of the Act's passage were the legal basis for rate determination, its effect on the quality and quantity of electrical power available to the Northwest aluminum industry, and an analysis of electrical rates likely to result from its passage. Technology used by the industry for smelting and environmental control was described, along with probable changes as a result of the conservation incentives in the act.

The primary effort in this study was devoted to analyzing the provisions of the Pacific Northwest Power Act under which the Bonneville Power Administration (BPA) will set future rates for the aluminum companies.

The next step was to acquire rate projections, as derived from the rate basis allowed under the Act's provisions. These were obtained from BPA's case studies, which were used in Congressional testimony on the Northwest Power Act. Each projection was based on different assumptions regarding costs of new resources, load growth, and implementation of various energy programs in the region. A base case was selected from these to represent the most likely rate levels. These were then compared with rate projections for TVA regions to determine whether Northwest smelters would remain competitive with smelters in these regions. Some comparisons were al so made to overseas rates, particularly those in Japan. 
The smelting and environmental control technologies of the industry were reviewed, and likely technological changes as a result of the conservation incentives in the Act were analyzed. The effects of the higher rates on energy costs for production and emissions control were then calculated. Control technologies used for meeting present and future environmental standards were examined to determine if they would affect the Northwest aluminum smelters under the new power rates.

The Pacific Northwest Power Act is not likely to have a significant impact on the ability of the industry to meet present or future environmental standards. The Act primarily affects the cost of electrical energy, but envi ronmental control uses no more than 1 percent of industry power requirements. In addition, the choice of systems is unlikely to be affected, because the dry scrubbing systems are superior to any other for meeting future emissions standards. The conservation retrofits will have, if anything, a favorable effect on emissions.

The impact of the act on conservation is likely to be substantial. Under its provisions, the companies will receive fixed allocations of power. =hus, the on ly means by which the companies can increase production in the future is through energy conservation; i.e. by using less electricity per pound. However, the industry will continue to be attracted abroad despite the mandated solution to Northwest power planning problems, because of the proximity to bauxite sources and cheaper power.

The most likely retrofits will consist of modifications to existing pots, including thermal insulation, computer controls, and electrolyte changes. The use of titanium diboride cathodes seems possible in the more distant future, but industry spokesmen indicated there are unresolved problems with cathode life and relative cost. The most significant conservation method would involve use of the Alcoa process to replace Hall-Heroult cells. However, this method would involve replacing existing plants entirely, which is not likely in the near term because only a pilot plant has presently been built, and its performance characteristics are still unknown. Recycling is also unlikely to become more important than at present due to the lack of an extensive secondary industry in the area to produce usable wastes. 
Finally, the results of this study indicate that the Northwest industry will be increasingly uncompetitive with smeiters in the Midwest, further discouraging expansion in the Northwest. However, these smelters should suffer no disadvantage relative to Japanese smelters. 
.

'

. 


\section{INTRODUCTION}

Over $60 \%$ of the 630 trillion Btu used in smelting, refining, and milling of nonferrous metals are consumed by SIC 3334 (primary aluminum) and SIC 3353-3355 (aluminum fabrication). Also aluminum production consumes almost $4 \%$ of the electric energy generated in the U.S. Not only is the sheer size of energy consumed by aluminum significant for a single industry, but aluminum is one of the largest users of energy per pound of final product produced. Aluminum is also important from a national perspective because it is a key material for many energy related activities such as cables for the transmission of electricity and collector plates for solar heating. All of these considerations make aluminum especially interesting for studying potential legislative impacts on the amount of energy consumed. In response to this interest, the Pacific Northwest Laboratory (PNL) contracted with the U.S. Department of Energy to study the energy and environmental implications of the Pacific Northwest Power Planning and Conservation Act on the aluminum industry.

This report examines the aluminum industry's technology in energy use and emissions control. Data on consumption and pollution levels are presented. A history of the aluminum industry in the Pacific Northwest, its role in providing power reserves, and how that role fits into the present power situation are given. The Northwest Power Act, the rates the industry will probably pay as a result of the Act, the implications of those rates to the industry, as well as the availability of federal power to the industry are discussed. Finally, the Act's effects on the relative competitiveness of the industry in both domestic and world markets are examined.

\section{LEGISLATIVE FOCUS}

The Pacific Northwest Laboratory (PNL) chose to focus on the impacts of the Pacific Northwest Power Planning and Conservation Act (previously S.885 and H.9020, now Public Law 96-501) in its study of the implications of federal legislation on the aluminum industry. This Act, recently passed by the Congress in November, 1980, was selected by industry spokesmen as the most important single piece of legislation affecting it. The Act gave the Bonneville Power Administration (BPA), the federal power marketing agency for the Pacific Northwest region, authority to provide long-term power contracts to 
the aluminum industry. These contracts specifically provide fixed proportions of firm and nonfirm power and enable BPA to continue to market power directly to the industry. These provisions are expected to dramatically affect the price the Northwest aluminum producers will have to pay for electrical power.

Electrical power availability and rates are very important to the industry. Nearly $85 \%$ of the energy used in aluminum reduction is electrical energy (Census of Manufactures 1977, p. 4-22). As much as 25\% of the total cost of primary aluminum is accounted for by electricity, so any variations in electricity prices will greatly affect the cost of metal. In addition, the heavy capital cost of aluminum smelters requires that they run continuously. Power interruptions are therefore very costly on this basis alone, as are the opportunity costs of lost production. The Act guarantees the industry certain percentages of firm power and partial compensation to the industry for an interruption.

The National Energy Act (NEA) was also examined by PNL. The fuel use and coal conversion provisions of the act (the Industrial Fuel Use Act of 1978, PL 94-620) appear to be of little importance. First, natural gas constitutes only $3 \%$ of the energy used in aluminum reduction. Petroleum is used mainly in the form of petroleum coke as part of the anode in the electrolytic reduction process. In addition, this part of the NEA is designed for major fuel burning installations, which are defined as "stationary units consisting of a boiler, gas turbine unit, combined cycle unit, or internal combustion engine.. (with)... a fuel heat input rate of 100 miliion Btu per hour or greater" (DOE, Office of Puiblic Affairs 1978, p. 3). Because fuel used for heat by the 31 domestic reduction $\mathrm{plants}$ amounts to less than 100 million Btu per hour, these plants would not be classified as major fuel burning installations subject to the conversion provisions. Fuel usage, in units of $10^{9} \mathrm{Btu}$, is natural gas $(17,940)$, Propane and LPG (418), Distillate $0 i 1$ (691), and Resdiual $0 i 1$ (625) (Census of Manufactures 1977, Table 3, pps. 4.22-4.25). Assuming that the 31 domestic smelters run at $90 \%$ of capacity during a given year, the use per hour totals 80 million Btu per plant, per hour. In section 302 of the National Energy Act, the Secretary is authorized to prohibit on a case-by-case or categorical basis, major installations from using $0 i 1$ or natural gas if the installation has the ability to switch to coal without undue financial or 
technical 10ss. However, the Department of Energy has not expressed any intent to require conversion by the aluminum companies.

The aluminum industry does generate some of its own electricity, which constitutes about $30 \%$ of its total requirements. Of the thermal $f$ acilities, about 50\% of the energy output is gas-fired (Coward and Sparrow 1980 p. 61). Whether these plants will be required to convert at this time, is not yet clear although the act does apply to such facilities. However, even if conversion does take $\mathrm{place}$, self-generated thermal energy is expected to be of declining importance to the industry. The percentage of electricity that is self-generated thermal energy has already fallen from nearly $30 \%$ of total use to $19 \%$ (Census of Manufactures 1977, p. 4-24). Construction of new thermal facilities is unlikely unless they are part of a power pooling arrangement because the use of self-generation forces the industry to pay the full marginal costs of that facility when used entirely by themselves. In the past, when thermal was less costly and hydro power was available, self-generation could be relatively cheap. For example, Alcan's power has been priced from its own hydro at around 2 mills per $\mathrm{kWh}$, in a memorandum from Jack Holtzapple, power manager at Kaiser Aluminum. For the Northwest Washington Public Power Supply System nuclear plants, power costs are given as 3 cents per kWh (Levy $1980 \mathrm{p}$. 48).

The Public Utilities Regulatory Policies Act (PURPA) is also applicable, primarily because of its effects on utility ratemaking procedures. Provisions related to natural gas pricing (Title III as well as the Natural Gas Policy Act) might affect the cost of gas supplies, but the effects relative to those from changes in electrical power costs will be small for the resons noted above. Other provisions related to cogeneration and small hydro facilities may be applicable but also of minor importance. However, PURPA does require that ultilities consider certain rate-making standards that might affect the costs of power delivered to the aluminum industry by BPA. These rates are based on costs, including long-run marginal cost and time-of-day-rates, declining block rates, and interruptible rates.

The DSIs do not support a cost standard based on marginal costs. Little likelihood of such a standard being adopted exists however, because $B P A^{\prime}$ s enabling authority does not permit such a standard when marginal-cost 
pricing would result in revenues to BPA in excess of recovery of average cost and investment costs (Levy $1980 \mathrm{p} .41$ ). The Northwest Power Act does not incorporate a long-run marginal cost standard and PURPA does not supersede the original legislation establishing BPA. However, a cost-of-service standard was incorporated in the Act as an adjustment for post-1985 DSI rates. Under th is circumstance, it is unclear if the DSIs would be subject to any further cost standards of this type as a result of PURPA.

Time-of-day rates are probably inappropriate for encouraging the Direct Service Industrial Customers (DSI) to conserve energy because of their tendancy to run at a constant pace around the clock. However, such rates are already in use by BPA for the DSI's so no extra impact will result from PURPA on this basis. The provisions related to declining block rates are inapplicable because PURPA requires their elimination and BPA does not use this standard. Interruptible rates are supposed to be considered by utlities under PURPA, but these $h$ ad 1 ong been a feature of aluminum industry power contracts in the Northwest. The Northwest Power Act does not contain provisions for interruptible rates. However, DSI power is still nonfirm and this aspect willsatisfy the one intent of an interruptible rate, that nonfirm power can be used as a form of reserve. Bonneville recognizes several reserve values for different uses. These include capacity, energy, and stability reserves. Therefore, PURPA does not seem to be very important from the aluminum industry viewpoint because either the standards it requires are inapplicable under existing 1 aw, such as marginal cost pricing, or are already in use. 


\section{TECHNOLOGY OF THE ALUMINUM INDUSTRY}

THE REDUCTION PROCESS

All aluminum ingot in the United States is produced by reducing aluminum oxide using the Hall-Heroult process. This process has been modified over time, but it has remained the primary method. Competing processess such as Alcoa, Toth, or Alcan are not discussed here. Only the Alcoa process is close to commercialization, and because this process requires an entirely new facility, its relevance to the Northwest industry in the near future is limited.

The Hall-Heroult process shown in Figure 1 is an electrolytic reduction using carbon and electrical energy to reduce aluminum oxide to aluminum and carbon dioxide. Each reduction cell consists of a steel shell with a carbon lining. Electrical power is fed to the cell through carbon anodes to a molten aluminum cathode. The cell also contains a molten electrolyte, generally cryolite which operates at close to 1000 degrees $C$. Alumina powder is fed into the bath from the top through holes made in the crust. Molten aluminum is then siphoned off periodically. The gasses produced by the reaction are allowed to escape through holes in the crust and are drawn out of the cell area by ducts. The entire cell is hooded to increase thermal efficiency by preventing heat loss and also to prevent the escape of gases.

A modern cell generally has 2 rows of 16 anodes. The cells are wired in series. A pot line contains many pots similarly wired. Silicon rectifiers are used to convert alternating current into direct current. In the largest cells 200,000 amperes are used. 50,000 amps are used in the oldest and genera11y smallest. An average figure might be on the order of 100,000 amperes. Current rectification is accomplished at nearly 97\% efficiency and total current efficiency for an average process is around 88\% (Beck 1977 p.141). The energy consumed in a Hall-Heroult cell is expressed by the relationship shown in equation 1 .

$$
\text { Kwh/1b. }=\frac{135 \times \text { Ce11 Voltage }}{\text { \%Current Efficiency }}
$$




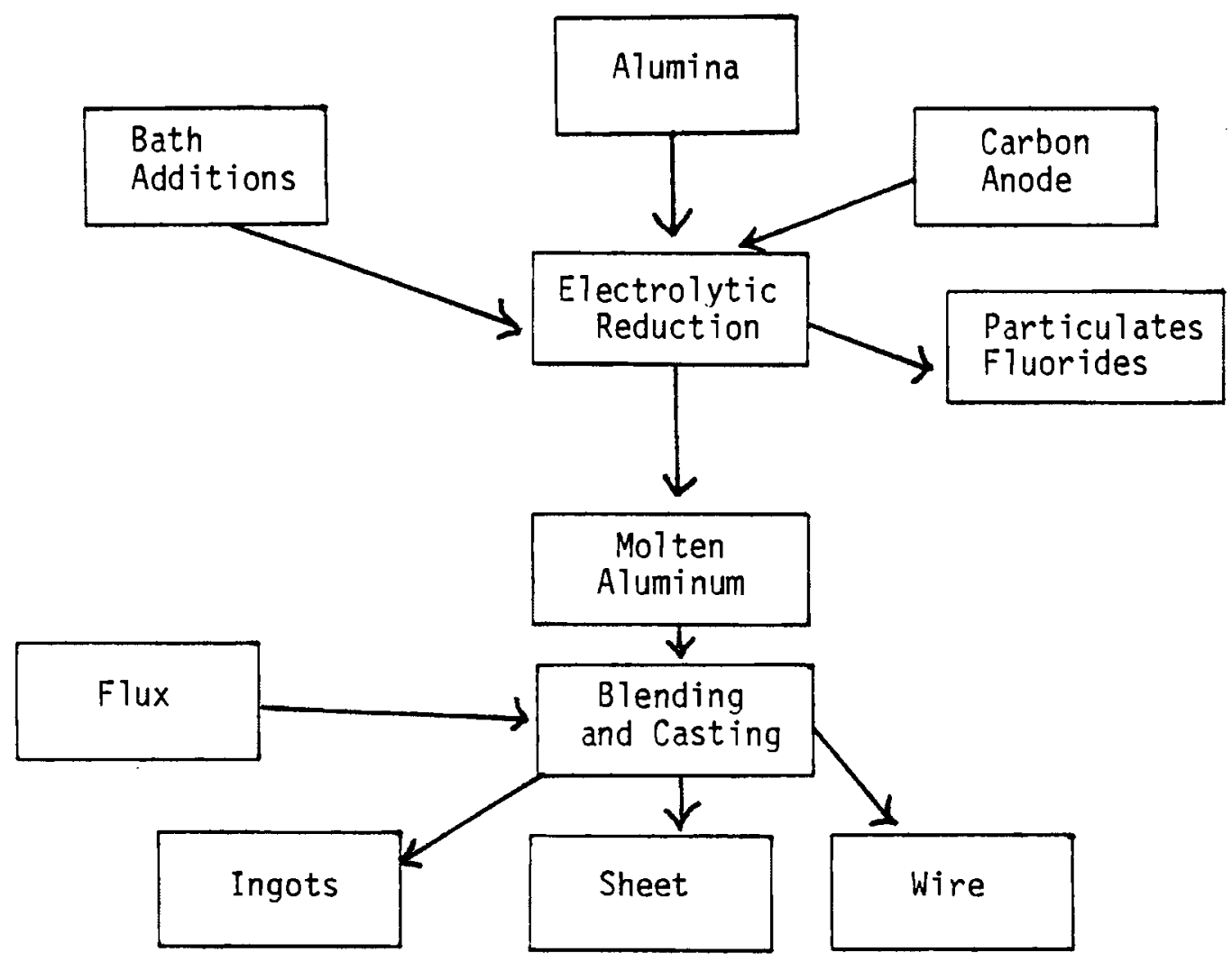

Figure 1. Flow Chart for the Hall-Heroult Process

Source: Boercker 1978, p. 21. 
At a typical cell voltage of 4.5 volts and $88 \%$ efficiency, the energy required is $6.9 \mathrm{Kwh} / \mathrm{lb}$. From equation 1 , the on ly way to reduce energy consumption then is to either decrease the cell voltage or increase the current efficiency.

The carbon for the reduction process comes from anode consumption which occurs during this process at the rate of 0.5 pounds of carbon per pound of aluminum (Boercker 1978 p. 23). Much of the energy used in aluminum production is used in the preparation of these anodes. Table 1 shows the relative energy usage figures. Of the total energy in aluminum reduction, the anode consumes about 15\%, which includes the petroleum coke and pitch, as we 11 as the natural gas for baking the anode. In absolute terms, consumption of petroleum coke makes the aluminum industry one of the largest consumers of petroleum coke(Boercker 1978. p. 26). About $70 \%$ of U.S. cells use pre-baked anodes (Boercker 1978 p. 23) which are formed by baking a paste of petroelum coke and pitch with a fuel. This fuel is usually natural gas, but coal or fuel oil could aiso be used. The continuous variety or Soderberg anodes, consists of a carbon-pitch paste fed into an anode casing and baked by the heat of the bath. Anode baking energy consumption is lower however for the pre-bake system $(1,130 \mathrm{Btu} / \mathrm{lb}$ ) versus $5,700 \mathrm{Btu} / 1 \mathrm{~b}$. for the Soderberg system (Charpie and MacAvoy 1978p. 34). In addition the pre-bake system is considered to be cheaper overa11 (Boercker 1978 p. 23). Fina11y, the Soderberg system releases hydrocarbon gases that are an occupational hazard requiring special hooding. As a result, only $30 \%$ of existing smelters use the Soderberg system and new ones are not expected to be built. RES IDUALS CONTROL

Primary reduction of aluminum generates both air and water residuals. Environmentaliy, the most serious of the air residuals are particulates and gaseous and particulate fluorides. Fluorides result when the addition of calcium and aluminum fluoride are added to the bath. Calcium fluoride is used to lower the melting point of the bath and aluminum fluoride is added to reduce aluminum solubility in the bath. Lithium fluoride is also sometimes used to lower resistivity. Gases emitted from the potline include carbon dioxide and carbon monoxide. Aluminum oxides are given off as dust or particulates. The anode baking room gives off burnt hydrocarbons as well as SOx and COx. 
Table 1. Energy Form Used in Aluminum Reduction

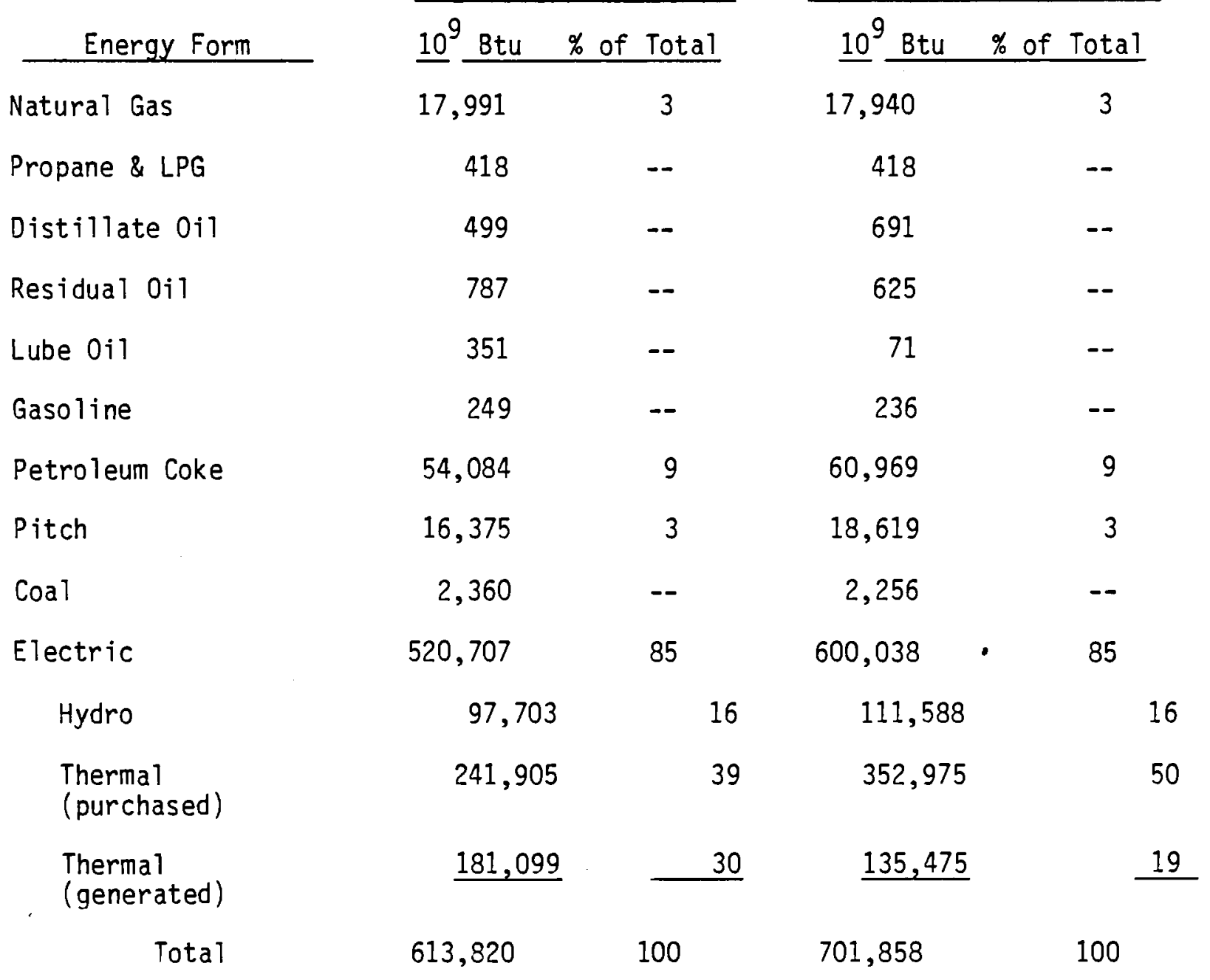

Source: Census of Manufacturers, 1977 pps. 4-22 through 4-24. 
The control technology for the air emissions consists of a hooding system to trap the gases and dust and draw them through a scrubber system or electrostatic precipitator. Both the wet or dry variety scrubber systems can be used on the potlines. The energy used in these systems is relatively small compared that used for production; less than $1 \%$ of the total Btu consumed (Arthur D. Little 1976 p. 88). In addition, about 90\% of the energy used for control is used for potline control (Hassoun 1978 p. 26).

The most serious water effluents produced in aluminum smelting are fluorides and suspended solids, produced by wastewater from wet scrubbing systems for the potline and anode baking room emissions. If the anode is the Soderberg type, the wastewater will generally include the tars and oils normally associated with anode baking.

Dry scrubber systems do not result in water pollution problems. However, such systems are not applicable to all plants because very tight hooding is required to produce a high concentration level of the pollutants. These systems operate by using dry alumina as an absorbent. The combined alumina and fluoride can then be returned to the cells and used in the reduction process. The recovery of the fluorides is thus virtually total in such systems.

A variety of wet scrubbing systems exist. The one advantage of such systems is that they can be used whether or not the hooding system is tight. They can therefore be used on Soderberg cells of all types, as we 11 as the older pre-bake cells. In addition, if dry systems are retrofitted to plants without tight hooding, a wet system can be used as a secondary treatment source. Treatment methods for the wastewater produced by such systems vary. A typical method would be to precipitate the fluorides followed by recycling of the cleaned water. The precipitating elements include cryolite and lime. other methods include recylcing with a follow-on alumina treatment and a recycled treatment combined with lime filtration.

Control of anode baking room emissions also varies. If wet scrubbers are used, the wastewater contains, as noted above, tars, oils, SOx, COx, as wel1 as fluorides in cases where the anode materials are recycled from the cells. Electrostatic precipitators are hazardous to use because the tars and oils can arc and burn in the precipitators. In cells where Soderberg anodes are being 
used, a variety of techniques that work even with the extra pollutants are available. With the vertical stud cells, the hooding can be tight enough so that the hydrocarbons from the anode are burned in the cell leaving only carbon dust to be removed from this source. The horizontal Soderberg cells are more difficult to hood and in some plants the emissions not captured by the hood must be removed by a duct system to a scrubber. In addition, the incomplete hooding does not result in the hydrocarbons being burned, so heavy hydrocarbons tend to foul the scrubbing system. Particulate capture also varies among the systems. In relative terms the vertical Soderbergs allow for $80 \%$ particulate capture, while the horizontal systems can only capture $50 \%$. The best prebake systems can capture 95\% of the particulates (Arthur D. Little 1979b p. 136). EMISSIONS LEVELS

The aluminum companies are required to monitor fluoride, particulate, and suspended solids emissions on a monthly basis and report them to their state environmental office. In Washington these data are collected by the Washington Department of Ecology. In Oregon they are collected by the Oregon Department of Environmental Quality. These two agencies were visited by PNL to obtain environmental data on the aluminum industry in the Pacific Northwest.

Table 2 presents a sumary of the 1979 air and water emissions data for nine of the Northwest aluminum smelters. The air data in this table show a moderate variation, among plants with a standard deviation of 20 to 39 percent of the mean. However, the 1979 monthly data for the individual plants show at least as much variation from month to month within a single plant. The standard deviations for this monthly data for each plant range from 11 to 88 percent of the mean with most falling in the 30 to 40 percent range. Thus, the air emissions from the Northwest aluminum smelters can be reasonably represented with the single number coefficients in Table 2 in the "Northwest Average" row for modeling or comparison purposes.

The water effluents in Table 2 show more variation among plants than among the air emissions, with standard deviations from 125 to 176 percent of the mean. In single plants, however, the standard deviations of the monthly data range from 7 to 143 percent, with most values falling in the 10 to 25 percent range. Thus, it is probably not valid to use the Northwest averages to 
Table 2. Average 1979 Air and Water Emissions For Northwest Aluminum Smelters

\begin{tabular}{|c|c|c|c|c|c|c|}
\hline \multirow[b]{2}{*}{ Location (Company) } & \multicolumn{3}{|c|}{ Air } & \multicolumn{3}{|c|}{ Water } \\
\hline & $\begin{array}{l}\text { Total } \\
\text { Particulates } \\
\text { (lb/ton Al) }\end{array}$ & $\begin{array}{l}\text { Particulate } \\
\text { Fluoride } \\
\text { (lbs/ton Al) }\end{array}$ & $\begin{array}{l}\text { Gaseous } \\
\text { Fluoride } \\
\text { (lbs/ton Al) }\end{array}$ & $\begin{array}{l}\text { Fluorides } \\
\text { (lbs/ton }\end{array}$ & Al) & $\begin{array}{l}\text { Total } \\
\text { Suspended Solid } \\
\text { (lbs/ton Al) }\end{array}$ \\
\hline Vancouver, WA (Alcoa) & 10.48 & 1.55 & 1.00 & 0.13 & & 0.77 \\
\hline Wenatchee, WA (Alcoa) & 9.76 & 2.70 & 1.30 & 1.30 & & 0.45 \\
\hline Goldendale, WA (Martin Marietta) & 9.34 & 1.62 & 1.07 & 9.36 & & 5.94 \\
\hline Bellingham, WA (Intalco) & 7.24 & 1.55 & 0.41 & 0.54 & & 0.94 \\
\hline Mead, WA (Kaiser) & 12.35 & 1.76 & 1.50 & 0.062 & & 0.115 \\
\hline Tacoma, WA (Kaiser) & 14.40 & 3.10 & 1.61 & 0.18 & & N/A \\
\hline Longview, WA (Reynolds) & 12.50 & 1.49 & 1.39 & 1.75 & & 2.56 \\
\hline Troutdale, OR (Reynolds) & 9.92 & 0.76 & 1.38 & $N / A$ & & $N / A$ \\
\hline The Dalles, OR (Martin Marietta) & 9.80 & 1.67 & 0.49 & $N / A$ & & $\mathrm{~N} / \mathrm{A}$ \\
\hline Northwest Average & 10.64 & 1.80 & 1.13 & 1.90 & & 1.77 \\
\hline Standard Deviation (\% of mean) & $\begin{array}{l}2.12 \\
(20 \%)\end{array}$ & $\begin{array}{l}0.69 \\
(39 \%)\end{array}$ & $\begin{array}{l}0.43 \\
(38 \%)\end{array}$ & $\begin{array}{l}3.35 \\
(176 \%)\end{array}$ & & $\begin{array}{l}2.21 \\
(125 \%)\end{array}$ \\
\hline
\end{tabular}

Source: Washington Department of Ecology and Oregon Department of Environmental Quality 
represent water effluents for the Northwest aluminum smelters. The difference in water effluents among plants is due to the type of air pollution control used in the plant. Plants that use wet scrubbing systems to control air emissions would generally have higher water pollution levels due to the problem of disposing of the liquid scrubber sludge. Data on the type of air pollution control systems was unavailable for comparison with the water effluent data.

Multi-year data were obtained for on ly one plant. Figures 2.1 through 2.3 summarize the air emissions data from 1971 to 1980 for the Alcoa Wenatchee plant. Although the data points in these graphs are scattered, the general trend seems to show air emissions remaining at the same level, or increasing slightly over this time period. Figures 2.4 and 2.5 sumarize the water effluent data for the same plant. Water data were unavailable for years before 1975. These figures show a discontinuous improvement in the levels of water effluents around the end of 1977 , possibly due to an improvement in the water pollution control system. Alcoa was unable to confirm this.

As a reliability check on the environmental data from the state environmental offices, the 1979 data in Table 2 was compared to similar data for 1975 reported by the Bonneville Power Administration (BPA-Draft Role EIS, Appendix C, Chap. IV 1977). The results of this comparison, summarized in Table 3, show the 1975 and 1979 data to be roughly equal for air emissions and the 1979 data to be generally lower than the 1975 data for water effluents. The results are consistent with the Wenatchee plant, which shows only a slight upward trend in air emissions, but improving water effluent levels.

In general, the aluminum plants are significant, but not the dominant sources of pollution in the regions in which they are located. For example, the Reynolds plant in Longview is the only direct service customer in Cowlitz County and accounts for 8.6 percent of total particulate emissions, 2.3 percent of SOx emissions, 3.7 percent of NOx emissions, 3.3 percent of CO emissions, and 4.4 percent of total organic emissions. Although similar situations apply to many of the smelters, sometimes an aluminum plant is a major contributor to pollution in a region. For example, the Kaiser plants in Spokane account for 81.9 percent of the SOx in Spokane county (BPA-Draft Role EIS, Appendix C, p. IV-156). 


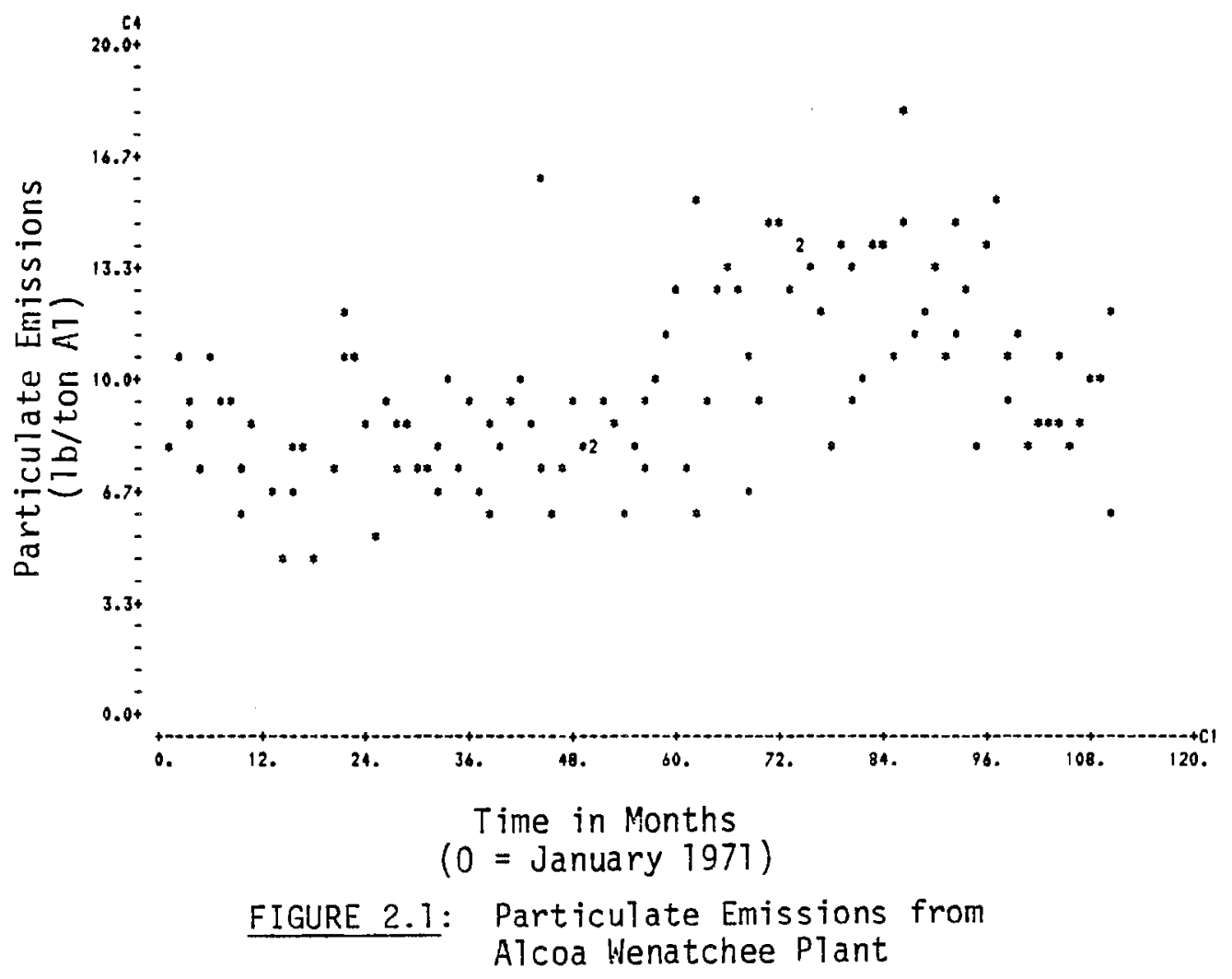



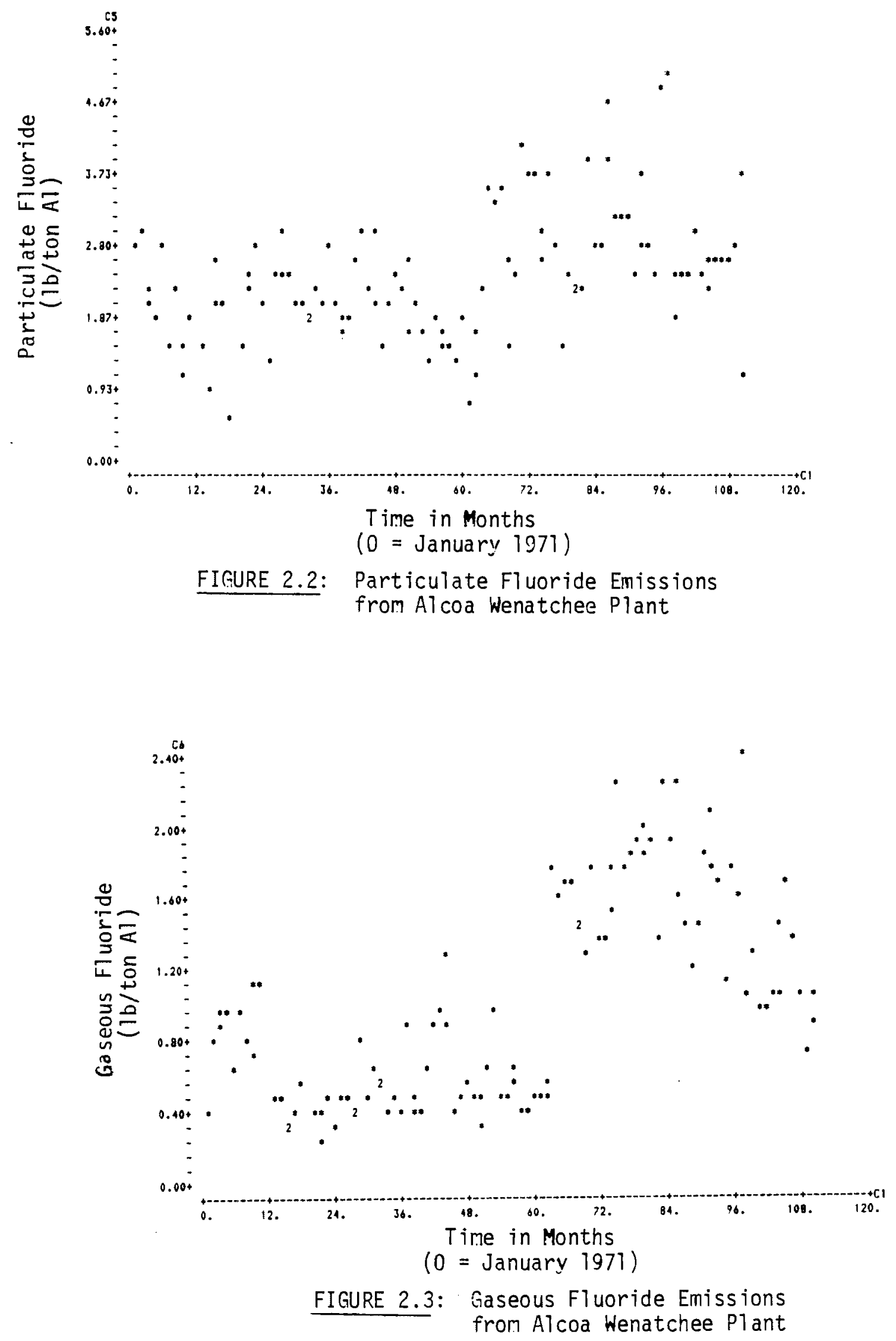


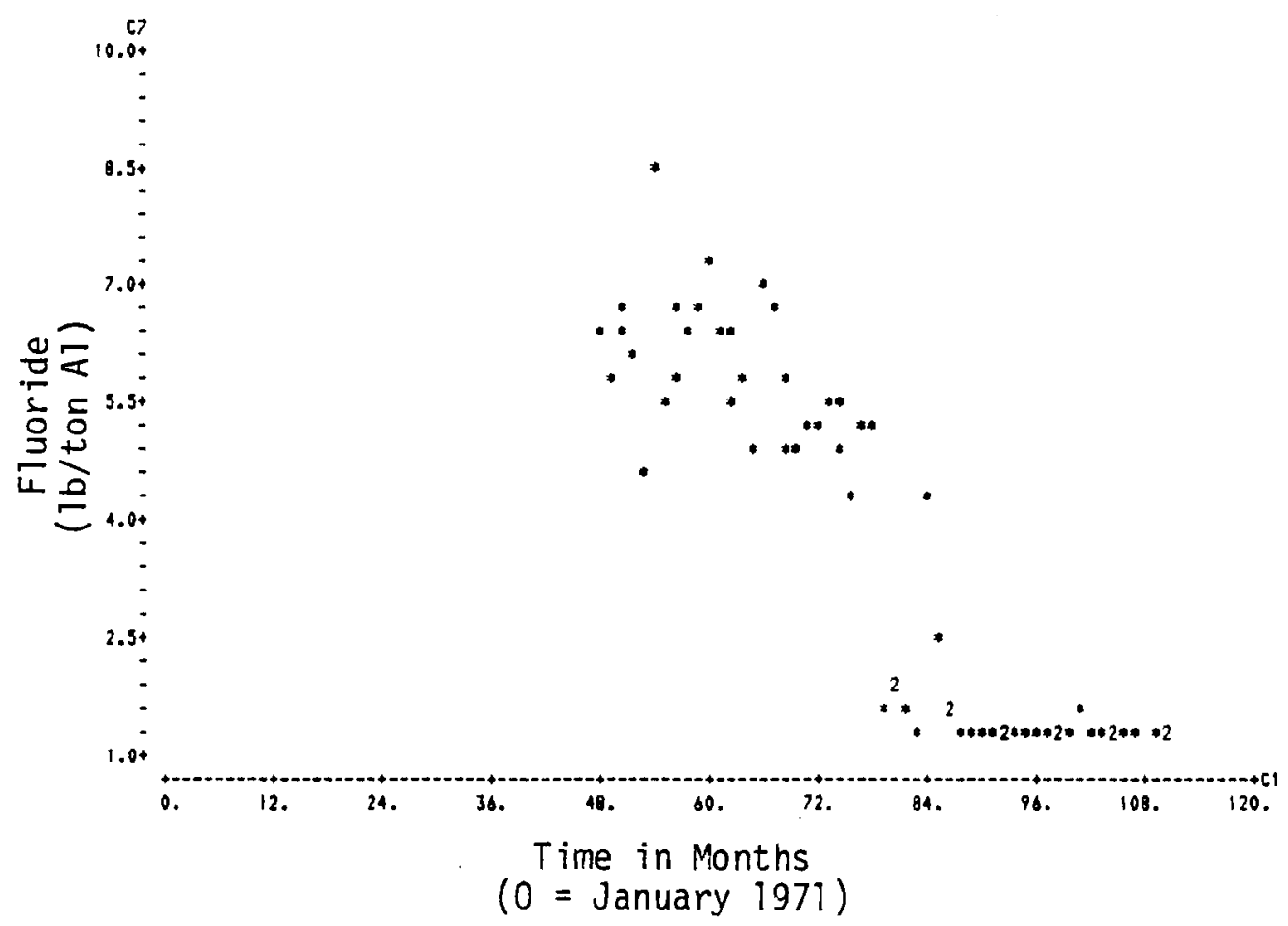

FIGURE 2.4: Water Fluoride Effluent from Alcoa Wenatchee Plant

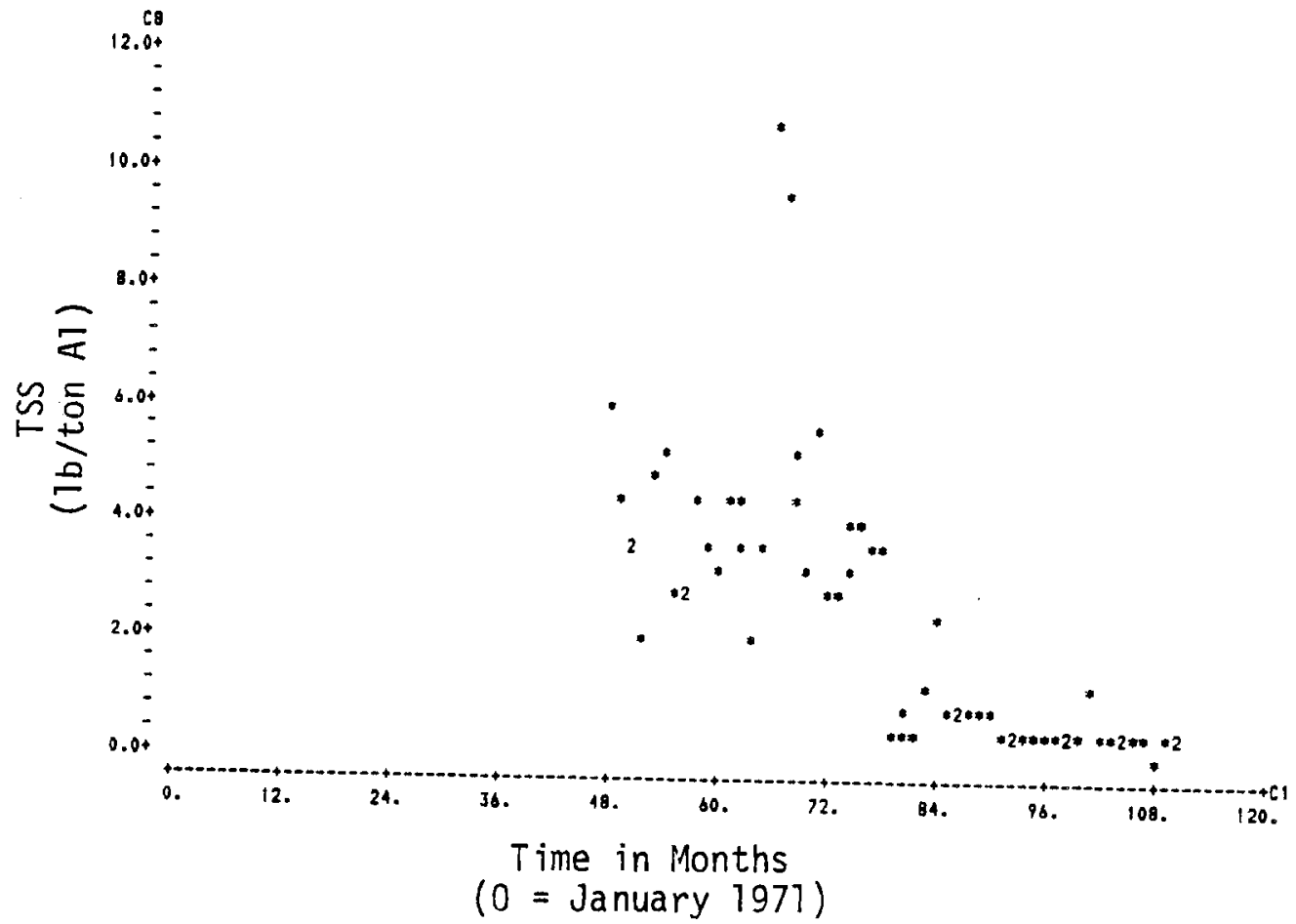

FIGURE 2.5: TSS Effluent from Alcoa Wenatchee Plant 
Table 3. Comparison of Air and Water Emission

Data With BPA Role Environmental Impact Statement (a)

Air Emissions

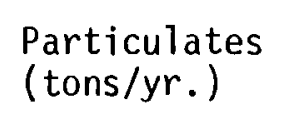

BPA PNL

$650 \quad 602$

N/A ${ }^{(b)} \quad 927$

N/A ${ }^{(c)} 537$

$N / A^{(b)} \quad 941$

$1405 \quad 1358$

$547 \quad 583$

$1346 \quad 1312$

$1612 \quad 645$

$N / A^{(2)} \quad 441$
Total Fluorides

(tons/yr.)

BPA PNL

N/A $\quad 146$

$N / A^{(b)} \quad 380$

$N / A^{(c)} \quad 155$

$N / A^{(b)} \quad 254$

$490 \quad 359$

$138 \quad 190$

N/A $\quad 302$

$N / A$

$N / A^{(b)}$
Water Effluents

Water Fluorides

(1bs./day)

BPA PNL

$44 \quad 38$

2998

771

4118

2647

428

418

38

38

1023

N/A

$N / A$

2899
Total Suspended Solids

(1bs./day)

BPA PNL

$655 \quad 228$

$1707 \quad 267$

$2387 \quad 1680$

$1618 \quad 620$

$5 \quad 70$

$7 \quad N / A$

$703 \quad 1497$

$424 \quad N / A$

$2163 \quad N / A$

(a) Bonneville Power Administration, Appendix C, pps. IV-153 through IV-170, July 22, 1977. Note that BPA data are for 1975, while PNL data are for 1979.

(b) Bellingham, Wenatchee, and The Dalles were all in compliance with ambient air standards in 1975 and air data were therefore not reported by BPA in the EIS.

(c) Air data for Goldendale, Washington were not reported in BPA EIS. 
THE ALUMINUM INDUSTRY AND ITS ROLE IN THE PACIFIC NORTHWEST

The Pacific Northwest Region consists of the states of Washington, Oregon, Idaho, and Montana west of the Continental Divide. This region is unique in that it contains one-third of the hydroelectric potential of the United States. This regional attribute has had a profound impact upon the development of the regional power supply and the aluminum industry. In this section, the history of the regional power supply is discussed, to present an overview of the industry's role in both the regional power situation and power planning. These considerations wil1 have an impact on how the industry is affected by the Northwest Power Act.

Early development of the regional hydro potential began with three U.S. Bureau of Reclamation (now the Water and Power Resources Service) projects. The first major construction of hydro facilities began when the U.S. Army Corps of Engineers started Bonneville Dam in 1933 and the U.S. Bureau of Reclamation started work on Grand Coulee Dam the following year.

In 1937, Congress enacted the Bonneville Project Act. This legislation created the Bonneville Power Administration (BPA) whose function was to market the power from Bonneville Dam, completed in 1938. The BPA was authorized to construct the transmission facilities necessary to market this power and to repay costs from power revenues. Eventually, BPA became the marketing agent for power generated at Grand Coulee Dam, completed in 1941, and the region's other federal hydro projects.

Completion of Bonneville Dam initiated a twenty-five year period of abundant hydro power. During this period, sufficient federal hydro power was marketed by BPA to serve the preference utilities, investor-owned utilities, and BPA's direct service industrial customers (DSIs) of which the aluminum companies are a major part.

Growth of the aluminum industry in the Pacific Northwest can be discussed in terms of three major growth periods. World War II was the the major driving force for the first period, which occurred during the 1940's. The second occurred because of the Korean conflict during the 1950's, while the third was related to a favorable power situation in the region during the middle 1960 's and early 1970's. 
With the completion of Bonneville Dam in 1938 and Grand Coulee Dam in 1941, the Pacific Northwest found itself with an oversupply of low-cost power. Partially to use this surplus power and partially to relieve the region's unemployment, the federal government sought the construction of an aluminum plant by the Aluminum Company of America (Alcoa), which at that time was the only aluminum producer in the U.S. In December 1939, Alcoa signed a 20-year contract with the Bonneville Power Administration to supply electricity to its Vancouver, Washington plant, which became operational in 1940.

With the outbreak of World War II, national defense needs created a large demand for aluminum. Availability of low-cost hydroelectricity made the Pacific Northwest especially attractive for aluminum production. Reynolds Metal Company constructed a reduction plant in Longview, Washington in 1941. This plant was partially funded by the federal government through the issue of low interest loans to Reynolds of up to $52 \mathrm{milli}$ on dollars. One of the motivating factors behind this loan was an attempt to increase competition in the industry. The federal government al so constructed aluminum plants of their own. Eight plants were eventually constructed at a cost of 180 million dollars (WP IRG 1978 p. 18), and included a plant in Troutdale, Oregon in 1941, a plant in Spokane, Washington in 1942, a plant in Tacoma, Washington, which opened in 1943, and several plants outside the Pacific Northwest. After the war the government was the second largest aluminum producer in the country (WPIRG 1978 p. 15). Following the war, these government-owned plants were declared surplus and were sold in a manner that promoted competition in the aluminum industry. This provision excluded Alcoa from purchasing any of the plants, so the Troutdale plant was sold to Reynolds and the Spokane and Tacoma plants were sold to Kaiser Aluminum, a new producer in the market.

In the 1950's, the Korean conflict provided the impetus for the second major expansion of the aluminum industry in the Pacific Northwest. During this period, existing plants increased their capacity and three new plants were constructed. Aluminum became a federal stockpile item with guaranteed markets and prices set at market levels. A new Alcoa plant opened in 1952 at Wenatchee, Washington. Anaconda Aluminum opened a plant in Columbia Falls, Montana during 1955 and Harvey Aluminum, Inc. (now Martin-Marietta) 
after many delays, opened its plant at The Dalles, Oregon, during 1958. Both Anaconda and Harvey were new aluminum producers. The Harvey plant, like many others, was supported by loan guarantees and market guarantees with advance payments for unproduced aluminum provided. (WPIRG 1978 p. 20).

The region's last period of aluminum expansion occurred because of an increased availability of low-cost electricity, resulting from the Columbia River Treaty which was signed in 1964 by the U.S. and Canada. This treaty authorized the construction of three new dams in Canada and one new dam in Montana, all of which resulted in increased hydropower by improving the seasonal regulation of the Columbia River. During this period, existing aluminum plants increased capacity and two new plants were constructed, one in Ferndale, Washington in 1965 and a Harvey aluminum plant at Goldendale, Washington in 1971. These plants were also financed with government aid. For example, the Washington legislature granted Intalco a tax credit worth 2.4 million dollars to induce Intalco to loacte in the state. (WPIRG 1978 p. 21).

During this period, the passage of the Pacific Northwest Regional Preference Act of 1964 further aided the industry's ability to obtain low-cost power. In this act, by stating that no federal power could be sold outside the Pacific Northwest unless it was surplus, Congress expanded the preference clause to protect the region. In other words, on ly federal power that was available after all the regional demands for power had been satisfied could be sold outside the region. This act was passed in response to the construction of the Pacific Northwest-Pacific Southwest transmission intertie, which connects the Northwest and Southwest power grids and allows for power exchanges between the regions during periods of shortage or surplus. This preference provision made the aluminum industry, the other DSI's, and the nonpreference utilities in the region the primary market for nonfirm Northwest power and the DSI role as a regional reserve further increased (discussed below).

Since 1940, when Alcoa opened the first Pacific Northwest aluminum plant in Vancouver, Washington, the industry has grown substantially. Today, 10 primary aluminum reduction plants exist within the region. These plants are very energy-intensive and consume approximately 20 percent of the region's firm energy supply (A.D. Little 1978 p. I-15), while producing one-third of the 
U.S. made aluminum ingots. These plants along with their construction dates, rated capacity, and anode type are shown in Table 4.

Historically, the federal government was interested in having the aluminum industry locate in the region because it provided a large stable market for sales of excess hydropower. The revenues from these sales contributed to the amortization of the hydro system costs. Also, because of the large loads of the reduction plants, the industry promoted earlier development of high voltage transmission lines at a much lower cost. The BPA notes that the capacity of the federal transmission system would be 15 to 20 percent less today without the industrial loads (DOE/BPA 1980). Overall, because of the industrial customers, the cost of power supplied by BPA has been estimated to be 1 to $2 \mathrm{mills} / \mathrm{Kwh}$ lower than it would have been without these customers $\left(\mathrm{CH}_{2} \mathrm{M} \mathrm{Hil1} 1977 \mathrm{p} .7\right)$. The high load factors of the aluminum industry have been ideal for exploiting the economies of scale available from large generation projects.

Defense needs arising from WWII and the Korean conflict clearly provided a second motive behind government support of the industry. The federal government supported Northwest expansion with loans and market guarantees, and even built facilities for its own production. Subsequent sales of the plants to producers other than Alcoa were made for competitive reasons, but the initial location decisions were not. Local governments have supported the industry with attractive financial offers to obtain tax revenues and promote local employment.

With time, the industry's interruptible power was used to serve as a form of power reserves for the region, through the interruption rights contained in the power contracts with BPA, described in more detail below. The features of these contracts allow the aluminum industry to act as a power reserve for the regional power pool because BPA has restriction rights on the top two quartiles of power to the industry under various conditions. The importance of these rights to the region and the role of the industry in the power pool can best be demonstrated by a discussion of the crisis arising in the region concerning new reserves and supplies and how the industry was affected, all of which led to the Northwest Power Act. 
Table 4. Aluminum Smelters in the Northwest

\begin{tabular}{|c|c|c|c|}
\hline (1) Location (Company)(a) & $\operatorname{Year}(\mathrm{a})$ & Smel ter Technology(b) & $\begin{array}{l}\text { Capacity } \\
\text { Short Tons/Yr. (b) }\end{array}$ \\
\hline Vancouver, WA (Alcoa) & 1940 & Prebaked Anode & 115,000 \\
\hline Longview, WA (Reynolds) & 1941 & Horizontal Soderberg & 210,000 \\
\hline Spokane, WA (Kaiser) & 1942 & Prebaked Anode & 220,000 \\
\hline Tacoma, WA (Kaiser) & 1943 & Horizontal Soderberg & 81,000 \\
\hline Troutdale, OR (Reynolds) & 1945 & Prebaked Anode & 130,000 \\
\hline Wenatchee, WA (Alcoa) & 1951 & Prebaked Anode & 190,000 \\
\hline Columbia Falls, MT (Anaconda) & 1952 & Vertical Soderberg & 180,000 \\
\hline The Dalles, OR (Martin Marietta) & 1955 & Vertical Soderberg & 90,000 \\
\hline Ferndale, WA (Intalco) & 1966 & Prebaked Anode & 260,000 \\
\hline Goldendale, WA (Martin Marietta) & 1970 & Unknown Soderberg & 115,000 \\
\hline
\end{tabular}

Sources: (a) Washington Public Interest Research Group Report 1978, p. 23.

(b) Coward and Sparrow 1980, pps. 41-42. 
THE ROLE OF THE DSIS IN POWER PLANNING

The Bonneville Project Act did not give the DSIs preference rights to Federal power as it did to publicly owned utilities and cooperatives. However, the act did give the BPA Administrator authority to negotiate contracts for direct consumption. The contracts with the aluminum industry were originally for firm power and rates were the same as BPA's sales to large utilities with a similar load factor (Allocations Policy Development Project; 1979 p. 2). Power shortages in 1947 induced BPA to sign the first interruptible power contracts, which provided for the use of energy produced from streamflow above critical levels to produce more aluminum. In 1954, BPA signed new contracts with a term of 20 years. These contracts provided for the delivery of advance or provisional energy to serve interruptible loads when streamflows were below critical levels and when interruptible power was not available. For BPA to continue to provide firm power for its other customers, the companies were required to return the energy by curtailing their firm loads if $B P A$ required it. The primary benefit from this provision was that more kilowatt hours were sold on average for any given streamflow.

The nonfirm power rights for BPA's large industrial customers became a normal feature of the regional power situation. Industrial plants would often expand before a supply of firm power was available and then negotiate with BPA when firm supplies opened up. After 1960, BPA began to require that firms take at least $25 \%$ interruptible, although the actual percentages for firms varied depending on past contract obligations. For example, Lyman Harris of Alcoa noted that Alcoa was all firm until 1974.

By the late 1960 's, BPA projected that future regional power needs would exceed total hydro capacity in about ten years. With the most promising hydroelectric sites already developed, thermal power plants would be needed to supplement hydro capacity. The Joint Power Planning Council was organized in 1966. This council developed a program called the Hydro-Thermal Power Program (HTPP), designed to coordinate the planning and construction of thermal resources on the basis of regional rather than individual utility needs. This plan consisted of two phases. 
The most important feature of Phase I of the HTPP was net-billing. This plan was designed to alleviate the projected regional energy problems without forcing curtailments of power to either preference customers or industrial customers. When one of BPA's preference customers entered into a construction agreement, they were providing a share of the plant cost for a portion of the output. BPA would then purchase that utility's share of the plant's capability by deducting that customer's annual share of the construction cost from their annual BPA power bi11. Hence, the term net-billing. This procedure allowed $B P A$ to increase its power supply even though BPA was not allowed to construct or own generating facilities.

During Phase I, BPA acquired through net-billing, 30 percent of the output of one currently operating nuclear plant, 100 percent of two WPPSS nuclear plants, and 70 percent of one other WPPSS nuclear plant. None of the WPPSS nuclear plants are operational and all are considerably behind schedule. Phase I ended when rapidly rising construction costs overtook BPA's ability to net-bill. However, during this time, BPA signed the first Modified Firm (MF) contracts with the aluminum industry, which provided for the interruption of the top quartile of DSI power at any time for any reason. The second quartile was interruptible only to insure system stability and the restriction period was limited to 500 times the contract demand (BPA, Role EIS 1980 p. IV-73).

A short-lived second phase of the HTPP was developed to overcome the difficulties preventing Phase I from continuing. Net billing and federal participation in the cost of non-federal thermal plants was discontinued. Federal construction of additional hydro capacity that was started during Phase I, was to continue. BPA was to act as an agent for the utilities agreeing to purchase power for them at the lowest possible price, engage in regional load shaping, and provide transmission facilities and power reserves.

A key element of the Phase II plan revolved around BPA's agreement to provide increased regional power reserves. To increase the amount of reserves available, BPA reached agreement with the aluminum industry and the other direct service industries (DSI) to secure additional rights to restrict service. In 1975, BPA signed interim agreements with the DSIs for Industrial Firm power. In return for increased restriction rights, the DSIs were to receive 20-year power contracts from BPA. In addition, all power was sold at 
the same rate. To compensate the DSIs for an interruption, an availability credit was developed which gave the DSIs credits for an interruption whenever power was not $100 \%$ available. As availability declined, the amount was to increase up to a limit of $\$ 9$ per kilowatt (Hassoun 1978 p. 105).

The interruption rights of BPA are explicitely defined in their power contracts (the IF-1 contracts). Before the passage of the Northwest Power Act, the industry operated on interim contracts while the provisions of future long-term contracts were being negotiated. These interim contracts contained the following interruption rights by BPA:

- The top $1 / 4$ of the DSI load and authorized increases can be withdrawn at any time for any reason for any duration.

- A second quartile of power can be withdrawn by BPA as necessary to avoid a firm energy deficit caused by the delay in completion or low output of one of the plants designated in Phase II of the HTPP.

- BPA may also make advance energy sales available to the DSI's by letting streamflows go below critical levels up to a limit of 800,000 Mwh, provided that this energy will be returned whenever BPA demands it.

- A stability reserve of up to $100 \%$ of total contract demand for up to 5 minutes and up to $50 \%$ of the operating load for up to 2 hours per day (subject to restrictions on the amount).

- The third quartile for a regional firm energy deficit due to a plant delay provided the DSI had been offered the opportunity to purchase part of the output. The passage of the Northwest Power Act makes this right viable because BPA can now offer to purchase the output of a generating plant.

These provisions provide the BPA system reserves and are generally the provisions for the new 20-year contracts offered by BPA under the Northwest Power Act. Clearly the industry's role in the Northwest power picture is significant. They have become not only an energy and capacity reserve, but a planning reserve as wel1. However, this long development, now codified by the new legislation will mean that the industry must pay more for ever lower quality power. The extent of the actual interruptions over time is set out in Table 5. These are not intended to represent future projections in any way. 
Table 5. Interruptible Power Deliveries Withheld from BPA Industrial Customers: 1968-1978

\author{
Operating Year(s) \\ $1969-1970$ \\ ( 3 restrictions) \\ $1970-1971$ \\ (2 restrictions) \\ 1971 - 1972 \\ (3 restrictions) \\ $1972-1974$ \\ (2 restrictions) \\ 1974 - 1975 \\ $1975-1976$ \\ ( 2 restrictions) \\ $1976-1978$
}

Total

\begin{tabular}{c} 
Duration of Restriction \\
\hline 2 months \\
6 days \\
17 days \\
26 days \\
5 months \\
24 days \\
35 days \\
14 days \\
14.5 months \\
12 days \\
3 months \\
10 days \\
1.5 months \\
14.3 months
\end{tabular}

Energy Withheld
(megawatt-hours)

469,807

19,386

231,600

65,184

$2,320,143$

279,731

116,927

175,441

$7,303,474$

252,720

876,884

248,002

995,592

$\underline{7,626,667}$

$20,981,558$

(a) To indicate the scale of these interruptions, the aluminum industries consume about 90 percent of DSI power. In 1976, they should have received about 2 million megawatt-hours/month. The energy withheld therefore represents an average loss of nearly 20 percent of the normal energy usage of the aluminum industry.

Source: Hearings Before the Committee on Energy and Natural Resources, United States Senate, p. 733. 


\section{THE NORTHWEST POWER ACT}

In 1966 BPA signed a contract to supply 327Mw of power to an aluminum reduction plant to be constructed by what is now the Alumax Corporation on the Columbia River near Warrenton, Oregon. Because of locally oriented environmental restrictions promulgated during 1974, Alumax decided to relocate the plant to Umatilia, Oregon. Upset with the proposed movement from Warrenton, the Port of Astoria and Clatsop County filed suit in the U.S. District Court of Oregon against BPA and Alumax on the validity of the new contract. A judgment in August 1975 ruled that the contract was valid but unenforceable until an environmental impact statement (EIS) had been filed.

The Alumax legal judgement precluded the completion of arrangements between BPA and Alumax and halted the other parts of Phase II of the HTPP pending completion of a major EIS. This judgment, together with the NRDC suit and further increasing costs for thermal plants, caused Phase II of the HTPP to be abandoned during 1975.

During this time, BPA realized that future federal hydro and net-billed thermal capacity would not be sufficient to meet future firm load demands of its preference customers. Therefore, in June 1976, BPA issued notices of insufficiency to its customers (not including the DSIs) stating that BPA could not guarantee to meet preference customer load growth after July 1, 1983. BPA also indicated that present contracts with direct service industries and federal agencies could not be renewed when they expired.

Notification to the DSIs was only one manifestation of future supply uncertainty. For example, two of the region's investor-owned utilities, had suggested that a ban be placed on new electric heating hookups. In addition, because of the preference clauses in the original acts and BPA's inability to acquire other resources when the HTPP program failed, the investor owned utilities had been unable to purchase firm energy from the federal system since 1973. As a result a growing disparity of rates existed between the preference utilities and the investor-owned utilities (IOU). The DSIs were becoming the focus of a regional power debate because of their access to federal power.

As the regional energy situation worsened, it became apparent that a coordinated regional effort was needed to solve the problem. Legislation, 
similar to the Northwest Power Act, and sponsored by the Pacific Northwest Utilities Conference Committee (PNUCC) and developed with the participation of regional industry, BPA, public and private utilities, and the states was introduced into Congress in 1977. In particular, this legislation attempted to preserve the industry's role in regional power planning and their direct access to federal power. However, the PNUCC bill would have weakened the preference clauses contained in the original BPA Act and the 1964 Act. Opposition to the bill grew until it was abandoned in favor of the Northwest Power Act.

\section{PROVISIONS OF THE ACT}

The Act provides BPA with expanded authority to purchase conservation and generating resources on a long-term basis to meet their customers' ful1 requirements. In developing new regional power resources, BPA is directed to invest first in conservation programs and then the development of renewable energy sources. Purchase of the output of traditional thermal facilities will be made only as a last option. The Act also establishes a public planning process for assuring non-utility input into regional power decisions.

The Act does negate some of the effects on rates to Investor-0wned Utilities (IOU) customers from their lack of access to federal power. As noted above, residential and farm consumers will have access to power at a rate equal to that for public bodies, cooperatives, and Federal agency customers. IOU load growth and regional rate customers not served by the federal system and IOU exchange will pay a new resources rate, the cost of which will be reduced by the use of the DSIs as a planning reserve through the right to withdraw power from the second quartile (among other features). In this manner, the DSIs role as a reserve for BPA will grow to become a regional planning reserve.

An important element of the Act to the DSIs is that BPA would be directed to offer new long-term (20-year) contracts for the sale of power both to preference and nonpreference customers. Without the purchase authority under the Act, it would be impossible to serve these contracts if a long-term deficit were forseen. For the aluminum industry and the other OSIs, the longterm contracts are a fundamental provision. In return for new contracts, the DSIs must give up their current modified firm contracts (MF) and accept more of 
their power on a non-firm basis similar to the interim industrial firm (IF) provisions underwhich they were previously operating. The new DSI contracts would be made for an amount of power equal to their current contractual entitlements and at higher rates, which first reflect the cost of the IOU exchange and later, the rising cost of new power supplies. The low-cost power relinquished by the DSIs would be partially used to supply residential and smal1 farm customers of investor-owned utilities, but on $1 y$ when the DSI's received an equivalent amount of power at the average system cost.

Under the Act the DSIs have only a fixed amount of power available for use from a conservation incentive standpoint. Increased power consumption is not possible under the Act except for authorized increases for such items as emissions control and the construction of the Alumax facility. Therefore, if the industry desired to increase aluminum output in the Pacific Northwest, it could do so only by increasing the efficiency of its power usage. The industry has indicated it intends to do this. For example, all vertical stud Soderberg smelters have gone or are presently undergoing a conversion to the Sumitomo process, which is expected to bring significant reductions in energy consumption per pound of aluminum produced.

POWER RATES UNDER THE ACT

Other provisions within the Act revise the basis for power rates. Preference customers and federal agencies would receive a rate based on the Federal Base System (FBS) cost, which is the lowest firm power rate. A preference customer rate ceiling is established for the period following July 1, 1985, to protect them from excessive rate increases. The ceiling essentially limits the preference customer rates to a level no higher than those they would have had in the absence of the Act. If the ceiling is triggered, the revenue needs that cannot be satisfied from the preference customers because of the ceiling will be recovered from all other BPA power schedules, including DSIs. The risk of this added cost is part of the cost of the Act to the aluminum industry.

The rates applicable to the DSI sales are divided into two time periods. Prior to July 1, 1985, rates charged will recover the cost of FBS resources required to serve the loads plus the otherwise unrecovered net costs of the 
investor owned utility exchange agreement. The power sold to the private utilities to service their residential and small farm customers will be at the preference customer rate, and power purchased in return by BPA from the utilities will be at their average system cost. Initially, the private utilities will be allowed to purchase enough federal power to serve 60 percent of such loads. The percentage will increase by 10 percent each year until all such loads are eligible. The cost differential from the exchange agreement will be paid by the DSIs. Following July 1, 1985, DSI rates will be required to be equitable in relation to the retail rates charged by BPA's preference customers to their industrial customers. These rates will increase if the preference utility rate ceiling is triggered. The DSI rates over both time periods will be adjusted to consider the value to BPA of the reserve function the DSI loads provide.

Actual calculations of the effective rates is somewhat speculative because loads and supplies are never known with certainty. However, use of BPA's projections gives some indication of the severity of the rate increases, which are codified in the bill under the rate-base provisions. Table 6 shows proejcted rates over time under the assumptions. In particular, the DSI rates shown here are predicated on the assumption that the Alumax load is served and the DSIs receive their contract entitlements subject to the restriction provisions of their contracts. The actual rates are, of course, not specified in the Act and must be approved through pubiic hearings.

The DSI rates are set on the base noted above and consist of two parts, the rates for IF power delivered and the reserve adjustment credit, which is related to the value of the reserves. The value of reserves is estimated by determining the amount of reserves provided by the DSI load, normally taken as one-half the DSI load. The cost of these reserves is estimated by determining the capital costs (average) associated with all new resources and the total federal system. This average cost times the amount of reserves equals their dollar value. The reserves adjustment credited to the DSIs was set equal to one-half the value of reserves to the region. This amount is then credited against the power interruptions and is denominated as milis per $\mathrm{kWh}$, which when multiplied by the total interruption in a given year gives the total payments to the DSIs. 
The composite rates shown in Table 6 are by no means effective rates to the DSIs. The composite rate calculations falsely assume that replacement power is always available at the rates specified in the table. If replacement power is not available at acceptable rates, then the aluminum plant must shut down potlines which gives $r$ ise to a different set of costs associated with the loss of revenues from the shutdown, eventual restart costs, and so on. According to Lyman Harris of Alcoa, potline restart costs can range anywhere from 0.5 to 5 million dollars. In the past, such power has not always been available, so the rates shown in table 6 are probably lower than the actual costs of power to the DSIs.

A11 actual rates must be approved by FERC, and the rates in Table 6 are older projections. Bonneville's recent proposals suggest that after July 1 , 1981, rates for sales to its preference customers will increase by $53 \%$ (Western Aluminum News, Apri1 1981, Vol 8, no. 3, p. 1). After October 1, 1981, these rates were projected to rise by between 159 to 234 percent above present costs, the difference will depend in large part on the exchange costs (ibid p. 1). 
Table 6. DSI Loads and Rates Projections

(a)

\begin{tabular}{|c|c|c|c|c|c|c|}
\hline Time Period & $\begin{array}{c}\text { Serviced Load } \\
\text { (Megawatts) }\end{array}$ & $\begin{array}{l}\text { Interrupted Load } \\
\text { (Megawatts) }\end{array}$ & $\begin{array}{c}\text { Base Rate } \\
(\mathrm{M} / \mathrm{kWh})\end{array}$ & $\begin{array}{l}\text { Reserve Credit } \\
(\mathrm{M} / \mathrm{kWh})\end{array}$ & $\begin{array}{r}\operatorname{IRE}^{(b)} \\
(\mathrm{M} / \mathrm{kWh}) \\
\end{array}$ & $\begin{array}{c}\text { Composite Rate } \\
(\mathrm{M} / \mathrm{kWh})\end{array}$ \\
\hline $1980-81$ & 3208 & 483 & 11.5 & 1.1 & 28.1 & 12.9 \\
\hline $1982-83$ & 3635 & 479 & 15.7 & 1.3 & 32.1 & 16.6 \\
\hline $1984-85$ & 3705 & 488 & 19.3 & 1.7 & 38.0 & 19.9 \\
\hline $1985-86$ & 3958 & 274 & 19.3 & 2.3 & 36.0 & 18.7 \\
\hline $1989-90$ & 4107 & 284 & 24.2 & 3.4 & 45.2 & 22.6 \\
\hline $1994-95$ & 4293 & 296 & 35.1 & 4.5 & 55.2 & 32.3 \\
\hline
\end{tabular}

(a) Source: Bonneville Power Administration - Appendix B to Report Accompanying S.885, pps. 69-71 1979.

(b) Industrial Replacement Energy 


\section{THE IMPACT OF THE POWER ACT ON THE NORTHWEST ALUMNINUM INDUSTRY}

\section{COMPETITIVE EFFECTS}

The preceeding chapter has indicated the range of electricity prices and power availability that Northwest aluminum producers will face. The important question to be answered here is whether these producers will suffer relative to those in other regions in the United States and other worldwide producers. Answers must be indirect because reliable comparative cost data are not readily available. This section presents evidence related to these questions.

During the 1950's and 1960 's, aluminum consumption grew at a fast pace of nearly 8 percent per year. This rate was double that of real Gross National Product growth in the same period. The rate for the 1970's was much lower, around 4 percent (Hassoun $1978 \mathrm{p}$. 5). This growth has been uneven during each period however, because the industry is cyclical. In the midfifties, for example, the industry overbuilt and suffered through slack demand periods. Since the industry is sensitive to general economic downturns, during recessions aluminum consumption tends to fall much more rapidly than real GNP. For example, during the 1974-75 recession, aluminum consumption fell over $30 \%$ (Commerce 1979 p. 4). These tendencies probably have resulted in some degree of caution about capacity expansion. Expansion was 13 percent in the 1950's, but fell to 7 percent in the 1960's and to 2.5 percent in the early 1970 's (Hassoun 1978 p. 53).

These figures are not necessarily indicative of an unhealthy future market however. Worldwide growth has been at a pace of nearly 7\% from 1967 to 1978 with projections of on $1 y 3 \%$ for growth in installed capacity in the near future (Light Metal Age, April, $1979 \mathrm{pg} .6$ ). Other projections are $5.4 \%$ growth in demand and $4 \%$ growth in worldwide capacity (American Metals Market, May 15, 1980). This slow growth of capacity relative to demand has meant a price rise from $20 \notin$ per pound in 1960 to projections as high as $\$ 2.00$ in 1985 (American Metals Market, May 15, 1980).

These figures suggest that the aluminum industry will not face totally adverse market conditions in terms of declining prices and falling demand. However, it is less clear that all of this is necessarily favorable to industry expansion or profitability. Some indirect evidence is given by the 
market price to supply cost ratio, which has fallen however from 1960 to 1975 (Bosworth $1976 \mathrm{p}$. 331). These costs include all operating cost components, as well as capital costs. If these numbers are any indication, the outlook for expansion is not as great as it would seem because various cost components such as bauxite, labor, and energy have been increasing at a rapid enough pace to offset the runup in industry prices. This idea is confirmed by the presently 1 imited industry expansion plans in the United States, with only the Alumax plant in South Carolina presently under construction and only one other project, the Alumax plant in Oregon, presently under consideration.

With regard to the industry's position in international trade, the industry may or may not have problems. The large rise in power costs in the Northwest may be attributed to the increased need for expensive thermal generation. However, in this regard, their international competitors may be no better, and in some cases, may be worse off. In Europe, the proportion of power generation based on hydro is $48 \%$, versus $47 \%$ for North America. For Japan and Western Europe, the figure is close to $30 \%$ (Skea 1980 p. 62). Japan is apparently even closing down as much as one fourth of its capacity because of high thermal costs (New York Times, January 17, 1979, p. D2). An independant source, Stan Smith of the California Energy Commission, put Japanese power costs at around 60 to $70 \mathrm{Mills}$ per $\mathrm{kWh}$. This figure is not unreasonable considering that Japanese electric power is very much petroleum based and useslittle hydro generation. The greatest increase in international competition may come from the less developed nations where hydro capacity could be greatly expanded, with as much $75 \%$ of total hydro expansion taking place in those regions (Skea 1980 p. 64).

One distinct disadvantage for the Pacific Northwest aluminum industry is that the largest markets for fabricated products are in the East and Midwest. Even so, the Pacific Northwest contains nearly one-third of domestic reduction capacity. The competitive problem for the Northwest producers is that they must ship ingot or semi-finished products to these areas. Only about one third of the industry's sales are in the western portion of the country. To compete in these markets, the prices of Northwest ingots must be lower by an amount equal to the transportation cost disadvantage. 
A simple method for evaluating the potential problem facing the Northwest producers is as follows. If on average, all production costs, with the exception of electricity, are assumed to be the same between the two regions, then power costs in the Northwest plus transport costs to the Midwest must be equal to power costs in the Ohio Valley. Transportation costs have been given at around 2.0 cents per pound of ingot. Power costs for the Ohio Valley were found from the Commerce study (Commerce 1979 p. 63) and are given in Table 7. Because the costs given in the study were in real terms, the numbers in the table are adjusted based on a $5 \%$ inflation rate for the period covered in the comparison. The Pacific Northwest costs were derived from BPA projections as given in congressional testimony on the Northwest Power Act (Boneville Power Administration, Report \#96-272 1979, pps. 56-79). Like al1 the figures in this report, they are meant only to be representative.

The assumptions made widen the differential between the Northwest and Ohio Valley considerably near 1985 and remains so for the remainder of the period covered. Although this sort of analysis has been done before, it does illustrate that even with the passage of the Northwest Power Act, ways to reduce electricity usage by Northwest producers may have to be found.

\section{ENERGY CONSERVATION}

Several ways exist to decrease energy consumption in the aluminum industry. One involves using an alternate reduction process to the HallHeroult process. Most often suggested as a viable alternative is the Alcoa Smelting Process (ASP). The ASP produces aluminum by the electrolytic decomposition of aluminum chloride in a fused chloride melt. The major advantage of the ASP is that it requires only $5.2 \mathrm{kWh} / \mathrm{lb}$ of electrical energy, a 25-45 percent improvement over the Hall-Heroult process (Arthur D. Little 1979a p. 68). Other alternate aluminum smelting processes are at least theoretically possible, but none are as near commercialization, or show as much promise for energy savings as the ASP.

Although the ASP offers the potential for substantial energy savings in primary aluminum production, it will not be considered in any depth in this study. One reason is that the aluminum firms have a great deal of capital invested in existing plants. Conversion to the ASP requires complete 
Table 7. Pacific Northwest Cost Differentials

\begin{tabular}{|c|c|c|c|c|}
\hline Years & $\begin{array}{c}\text { Ohio Valley }(\mathrm{a}) \\
\text { Power Costs } \\
\quad \notin / 7 \mathrm{~b} . \\
\end{array}$ & $\begin{array}{c}\text { Pacific (b) } \\
\text { Northwest } \\
\text { Power Costs } \\
\$ / 1 \mathrm{~b} . \\
\end{array}$ & $\begin{array}{l}\text { Transportation }(c) \\
\text { Costs } \\
\$ / 1 \mathrm{~b} . \\
\end{array}$ & $\begin{array}{c}\text { Differential: } \\
\text { Pacific Northwest } \\
\text { Ohio Valley } \$ / 1 b .\end{array}$ \\
\hline $1980-81$ & 1.54 & 1.29 & 2.0 & 1.75 \\
\hline $1982-83$ & 1.69 & 1.66 & 2.1 & 2.07 \\
\hline $1984-85$ & 1.87 & 1.99 & 2.3 & 2.42 \\
\hline $1985-86$ & 1.96 & 1.87 & 2.4 & 2.31 \\
\hline 1989-90 & 2.39 & 2.26 & 2.9 & 2.77 \\
\hline $1994-95$ & 3.05 & 3.23 & 3.6 & 3.78 \\
\hline
\end{tabular}

(a) Department of Commerce, 1977 p. 63

(b) Bonneville Power Administration - Appendix B to Report Accompanying S.885 1979, pps. 69-71. Note that the given rates are the composite rates and include the costs of replacement power and reserve credits. These figures assume, however, that replacement power is always available.

(c) Ernst and Ernst 1976, p. V-39. Assumes a five percent inflation rate for these costs. 
reconstruction of the plant. Even if the aluminum company were willing to build a new plant, it probably would not be constructed in the Northwest region. The large price increases and limited availability of electricity will tend to discourage construction of new aluminum plants in this region. Also, proximity to bauxite resources and more abundant energy will tend to attract the aluminum industry to build elsewhere. Thus, since this study concentrates on the aluminum industry in the Northwest, the only energy conservation techniques considered are retrofits that are applicable to existing plants in the region.

Table 8 shows a list of potential energy conservation retrofits that could be implemented in an aluminum plant and includes options that are already widely used in the aluminum industry, as well as options that are still undergoing technical development. The retrofits are categorized according to the component in the plant to which they apply. Since the primary pot, where the smelting of aluminum occurs, consumes nearly 70 percent of the total energy, and 98 percent of the electrical energy (Census of Manufactures 1977 p. 4-22), retrofits that concern the pot offer the greatest potential for energy reductions. However, other components such as the furnaces, anode bake plant, paste plant, and pollution control equipment are also substantial energy users and offer retrofit opportunities.

\section{PRIMARY POT ALUMINUM PLANT}

As noted above, the primary pot, or Ha11-Heroult cel1, accounts for the bulk of energy consumption in aluminum production. In the period since 1940, the average electrical energy required by the Hall-Heroult cells has decreased from the 8.0 to $12.0 \mathrm{kWh} / \mathrm{lb}$ Al range to the 5.6 to 8.0 range, representing about a 30 percent increase in energy efficiency. As noted in the previous discussion of smelting technology, the route to decreasing energy use lies in either decreasing cell voltage or increasing current efficiency. These two methods accounted for most of decrease in energy requirements.

Several methods exist to decrease cell voltage. One method involves reducing the resistivity of the electrolyte. However, using bath additions such as Tithium carbonate, this reduction has resulted in decreases of resistance of only a few percent. Another method is to control the anode 
Table 8. Energy Conservation Retrofits in a Primary Aluminum Smelter

1. Pot (primary)

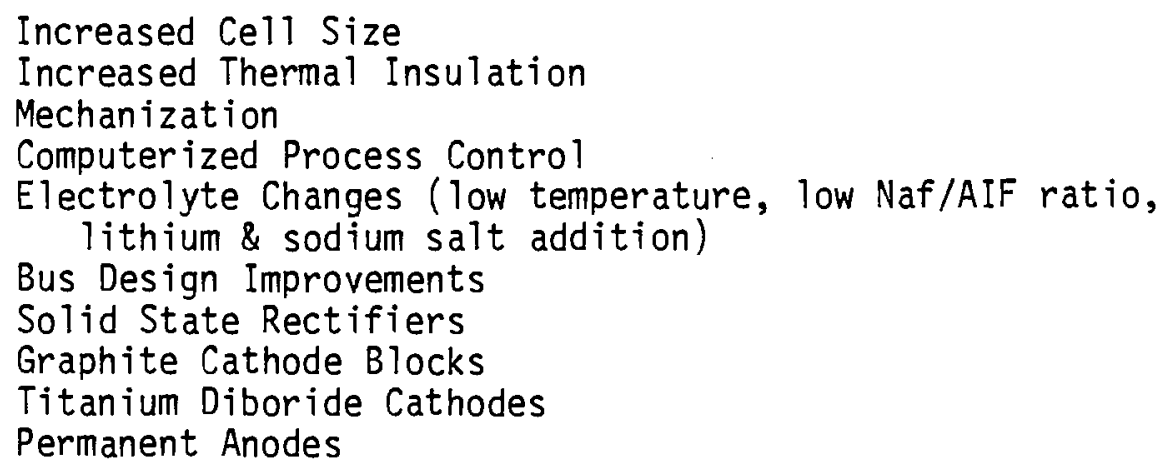

2. Casting Furnaces

Heat Recuperators

Automatic Pressure Control

Fue 1 Changes

3. Heat Treat Furnaces

Heat Recuperators

Direct Firing Instead of Radiant Tube

Fuel Changes

4. Anode Bake Plant

Heat Recuperators

5. Other Energy Conservation Measures

Increased Use of Recycling

Changes in Pollution Control Equipment 
cathode distance by continually repositioning the anode as it is consumed to el iminate any voltage losses. However, the most important and practicable technique to reduce voltage losses is to reduce current density by increasing the amperage. This, in turn, involves increasing cell size. The trend toward larger cells has been apparent both in new plants and in modernizing old plants. Larger cells not only improve energy efficiency, but al so have had the benefit of decreasing labor costs in relation to productive capacity.

Another method to decrease cell voltage is to increase energy efficiency. Viable techniques include thermal insulation to reduce heat losses, magnetic bus design improvements, and improved sidewall and bottomthermal insulation design. These techniques have decreased heat losses and adverse electromagnetic effects and have resulted in improved current efficiency and cell-lining life. Electrolyte composition changes have included the use of additives such as lithium fluoride and lower $\mathrm{NaF}_{\mathrm{A}} \mathrm{AF} / 3$ ratios to improve current efficiency and lower the cell voltage. Solid-state rectifiers (silicon diodes) have increased the efficiency of conversion from alternating to direct current. These changes have not been universally applied to all aluminum plants due to differences in design, costs, or other factors. However, the energy efficiency improvements that have been made to date can generally be attributed to some combination of these changes.

Cell control is one of the most important features of more modern plants using the Hall-Heroult process besides large cell sizes. Cell control is a complex subject, but generally, the problem concerns current efficiency. Negative factors include an anode effect when the alumina content of the cryolite electrolyte falls too low. In modern plants, such as the Intalco plant discussed below, computer monitoring can provide a signal to increase the amount of alumina in the cell. Another area is the control of anode height to break up $\mathrm{CO}_{2}$ bubbles, which interact with the molten aluminum, reducing current efficiency.

Of some interest from a conservation viewpoint is the Sumitomo process, a variant on the Soderberg anode type. This is a retrofit on the vertical stud Soderberg involving a change in electrode composition and a different hood system. While this conversion is usually done for environmental reasons, some indications show that energy consumption can be reduced by as much as 10\% (Bosworth 1978, tables 5 and 6 ). 
A 1 imit to further increases in the energy efficiency seems to exist in present Hall-Heroult cells using on ly the measures suggested above. One reason for this 1 imit is that decreasing current density in cells results in less aluminum produced per unit of cell and increased size of the potline building, which in turn results in higher capital costs per ton of capacity and a slower return on investment. The point has probably been reached where lowering current density will no longer offset increased capital costs in decreased energy costs, hough energy costs continue to rise (Beck 1977 p. 160). Also increasing cell size beyond about $225 \mathrm{KA}$ can adversely affect voltage stability, current efficiency, and cell lining life because of large electromagnetic effects and heat dissipation problems.

Despite these problems with further energy improvements, potential changes exist that could achieve greater energy efficiency in conventional HallHeroult cells. One potential change would be the use of graphite cathode blocks in conventional cells to achieve voltage reductions. Graphite cathode blocks could achieve a 2 to 4 percent reduction in energy use over the most efficient cell in use today (Beck 1977 p. 163). Also, a very low $\mathrm{NaF} / \mathrm{AlF}_{3}$ ratio, high LiF, low temperature electrolyte could achieve a 3 to 5 percent energy savings by reducing voltage in present potlines. A third retrofit that offers larger energy savings is the use of titanium diboride $\left(\mathrm{TiBr}_{2}\right)$ cathodes. A $\mathrm{TiBr}_{2}$ cathode is dimensionally stable under electromagnetic forces, electrolyte convection, anode gas evolution from the interelectrode space, anode changing, or other cell operations. The anode to cathode distance can be much less than in a conventional cell without causing severe voltage instability and loss of current (Beck $1977 \mathrm{p} .164$ ). This $\mathrm{TiBr}_{2}$ cathode characteristic offers the potential for increases in cell size, improvements in energy efficiency of 6 to 15 percent, longer cell lining life, and greater productivity per unit cell size. However, a cell life between three and four years is estimated to be necessary to justify the installation of $\mathrm{TiBr}_{2}$ cathodes. While laboratory experiments suggest that a life of 7 to 8 years is possible, in practice no one has demonstrated a sufficiently long life to justify the risk in retrofitting a number of production cells (Arthur D. Little 1979b p. 75). 
A final potline retrofit that could be used to increase energy efficiency is the installation of permanent or non-consumable anodes in the Hall-Heroult ce11. This installation would eliminate the need for a prebake plant. An overall efficiency improvement of 8 to 10 percent might be achieved if a suitable material were found for a permanent anode (Arthur D. Little 1979b p. 56). However, despite ongoing research, many technical problems remain with permanent anodes in addition to the selection of an appropriate material. If a suitable anode is developed, however, no certainty exists that it will be amenable for use as a retrofit in existing cells.

Energy conservation could be achieved in the aluminum industry through other means than retrofits to the conventional aluminum plant. One possibility for saving energy is to increase recycling. Because recycled aluminum requires on $1 y 5$ to 10 percent of the energy needed for primary production of a luminum from bauxite (Boercker 1978 p. 45), most aluminum companies already encourage recycling. However, in the U.S. only an estimated 20 percent of the aluminum used in industrial or customer end-product, is ever recycled as scrap (WP IRG 1978 p. 67). This may be partly due to the fact that purity of secondary aluminum is frequently lower than primary. Thus, recycled aluminum may not be applicable to some uses without some purification in secondary smelters. Even with purification, secondary aluminum is much less energy intensive than primary aluminum. In addition, in the Pacific Northwest, there is not enough readily available scrap appropriate for use. Most scrap is found in the Midwest where most fabrication occurs. Much local scrap, (Boeing in Seattle) is hard alloy material and has too much alloy impurity to be readily recylced into soft primary metal products.

CONSERVAT ION POTENT IAL

The previous section has provided an overview of the retrofits that are available or will become available to the aluminum industry. To obtain an idea of the potential energy savings from retrofits, PNL visited one of the most modern of the Northwest smelters, the Intalco smelter at Ferndale Washington, built in 1966 . This plant uses only about $6.5 \mathrm{kwh}$ per pound of aluminum using the basic Hal1-Heroult process. As is still the case for for worldwide smelting, none of the more advanced ideas such as the titanium cathodes are 
utlilized. Instead, the visit indicated that most of the advances were in the bath chemistry and in cell control. The tops of the aluminum baths were at ground level and easily accessible to mechanical equipment for breaking the cryolite crust. The anode bars are also automated and computer controlled. The computer control aspect is particularly important because anode height can be optimized and the amperage input can be higher with a lower voltage, the importance of which was previously discussed. Sources at Intalco gave this figure as 136,000 amps at 4.3 volts as opposed to 75,000 amps at 5 volts for the Kaiser plant in Spokane.

The average energy consumption of the Northwest aluminum industry is about $7.6 \mathrm{kWh}$ per pound. The Intalco experience suggests that nearly $1 \mathrm{kWh}$ per pound of aluminum could be saved by conservation. Even if half this amount were saved on the average, the energy savings would be substantial. One-half kWh per pound is roughly equal to 164 average megawatts of energy saved. 0ther sources have suggested that even larger savings are possible. A GAO study, concerned with modernizing the seven oldest plants to equal the best plant performance in the region, gave a figure of 500 average megawatts saved by 1990 (GAO $1980 \mathrm{pg} .12$ ). The aluminum industry has challenged those figures however (Industrial Customers of BPA 1980).

The $.5 \mathrm{kWh}$ figure is about $33 \%$ of the GAO figure, so an average savings of $1.5 \mathrm{kWh}$ is assumed if a 11 plants were roughly the same capacity. For some of the older plants, savings of well over 1.5 are possible. For example, according to Lyman Harr is of Alcoa, the Alcoa plant at Vancouver uses $10 \mathrm{kWh}$ per pound, which if brought down to $6.5 \mathrm{Kwh}$ per pound, would save about $92 \mathrm{Mw}$. Such large savings may or may not be technically feasible or cost effective.

In addition, the Industrial Customers of BPA report suggests that the actual costs of the smelter investments envisioned by GAO would cost about $30 \%$ more than assumed. Finally, because some of the investments that would save a great deal, such as the conversion of the vertical Soderberg smelters to the Sumitomo process, are already underway, and cannot be counted in the region's future potential. Other conservation measures such as the $\mathrm{TiBr}_{2}$ cathodes are not yet commercialized. However, as a minimum, the oldest plant in the region at Vancouver might be expected to reduce energy consumption from 10 to $8 \mathrm{Kwh}$ per pound, the Mead plant from $8 \mathrm{kWh}$ to 7 and the Troutdale and Wenatchee 
plants could contribute $1 \mathrm{kWh}$ each, assuming they are using nearly $8 \mathrm{kWh}$ per pound as well. If such a scenario is plausible, then the savings would be about 175 average megawatts, which represents a reasonable lower bound on the potential. In addition, these plants could save this energy by adopting known techniques such as automatic control, bath additions, etc.

The cost effectiveness of energy conservation to the Northwest aluminum industry depends strongly on the price and availability of electricity. Clearly, the more rapid the electricity price escalation, the more cost-effective energy conservation becomes. If electricity is in short supply, it could become a limiting factor to production. To see the importance of the level of energy prices and availability, consider the following example (Industrial Customers of BPA, 1980 p. 3):

A labor savings of $2.6 \$$ and maintenance savings of $.9 \$$ per pound is assumed. The amount of energy saved was given as $2 \mathrm{kWh}$ per pound. At a price of $20 \mathrm{mills}$, the energy savings are $4 \$$ per pound. The capital costs were given in the GAO report as $75 \$$ per pound. At a market rate of $12 \%$, the interest cost per pound is $9.0 \$$. Clearly such an investment is not cost effective unless interest rates were much lower, say at $9 \%$. If energy prices were much higher, such as $50 \mathrm{mills}$, then the investments would be cost-effective.

The nonfirm nature of DSI power is also important in considerations of cost-effectiveness. Under the Northwest Power Act, interruptibility rises to at 1 east $50 \%$, not counting the planning reserve. If the facilities were idle $20 \%$ of the time as a result, because no replacement power was available, then the actual effective capacity is 800,000 tons instead of 1.1 million tons and the unit cost for the example above, rises to $\$ 1.00$ per pound. Energy savings would have to be even higher to compensate.

RES IDUALS FROM ALUMINUM PRODUCTION

The Northwest Power Act's impact on the ability of the aluminum industry to meet its emissions requirements will be negligible. The Act's impact on emissions levels will be primarily through its effect on industry choices concerning energy-saving retrofits as a result from the necessity to conserve electrical energy. The general conclusion to be drawn from examining these retrofits is that they will have, if anything, a favorable effect on most types of emissions levels. In addition, although the Act will greatly raise rates for electricity, control equipment uses relatively small amounts of such power. For example, a plant producing 160,000 tons per year would use $26 \times 10^{6}$ 
kWh of electricity (Arthur D. Little 1979b p. 60), which is about .08 kWh per 1b. With a projected rise of nearly $3 \$$ per $\mathrm{kWh}$ in the price of electricity, this transiates into an extra operating cost of $0.2 \$$ per $1 \mathrm{~b}$. or about $\$ 650,000$ extra for the $\mathrm{plant}$ in operating costs.

Different emissions systems use differing amounts of energy. For example, the dry system uses about $233 \mathrm{kWh} /$ ton while wet scrubbing without recylce or secondary treatment, uses $84 \mathrm{kWh} /$ ton (Arthur D. little $1979 \mathrm{~b}$ p. 132). However, because these costs are so small relative to investment costs and other operating costs, the choice between systems is unlikely to be affected.

The retrofits can be discussed in turn. Some of these, such as heat recuperators, electrolyte changes, and automation will have no environmental effects other than indirect effects from reducing fuel consumption. However, under the Act, the only method by which the companies will be able to increase production will be to save electricity, so if substantial emissions benefits were realized in this manner, they would be negated by productionincreases. This is particularly true of the cell control operations that are the most likely retrofits from an energy savings standpoint.

Permanent anodes would eliminate the need for an anode baking plant. However, this part of the production facility requires only $10 \%$ of the electrical energy used to control emssions in the potlines, as noted in chapter III. In addition, the industry's most significant emissions are the fluorides and particulates from the potline. Differences in emissions from the potline would not be that significant. An exception to this statement is a process change involving a switchover of the anode baking furnaces from natural gas or oil to coal. Such a switch would increase both particulate and $\mathrm{SO}_{2}$ emissions from an aluminum smelter. To meet air emission standards, aluminum companies would then be forced to install scrubbers, which are not presentiy required for existing natural gas-fired furnaces. A less expensive alternative to scrubbers might be treatment of coal prior to combustion to remove sulfur and fly ash, such as in solvent-refined coal. However, the operating costs of new scrubbers would be small relative to the investment costs, which are not affected by the Act. 
Major changes in the potline include permanent anodes (discussed above), titanium cathodes, and the use of the Alcoa process. The latter requires virtually an entire new facility and presents entirely new emissions problems. The Alcoa system is very different from the Hall-Heroult process. The primary emissions problem is $\mathrm{SO}_{2}$ due to the combustion of coked and cracked fuel 0i1. In addition, near the end of the process, waste off-gases are subjected to a condensation process and water-leach filtration to remove the sodium chloride, that remains in the water solution. However, use of electrical power for a baseline 160,000 ton plant would only be about $6.4 \times 10^{6} \mathrm{kWh}$ per year compared to $26 \times 10^{6} \mathrm{kWh}$ per year for the existing Ha11-Heroult process (Arthur D. Little $1979 \mathrm{~b}$ p. 60). If the Act were to make this system attractive, then emissions control would be favorably affected.

Use of titanium diboride cathodes would also have favorable impacts on emissions levels per pound of product produced. The hard metal cathode would reduce the back-reaction in the anode, thereby decreasing the usage of the anode by about 20\% (Arthur D. Little $1979 \mathrm{~b}$ p. 74). Less burning of fuels for anode baking and a decrease in emissions of hydrocarbons for the Soderberg type would result. The volume of off gases would also be slightly reduced with a decrease in the emissions of carbon monoxide and an slight increase in carbon dioxide. However, the use of these cathodes would reduce energy usage substantially by as much as 20\% (Arthur D. Little, 1979b p. 74). The Northwest industry would increase production as a result, negating much of the improvement. 


\section{REFERENCES}

Arthur D. Little, Inc. 1978. A Regional Analysis: Economic and Fiscal Impacts of the Aluminum Industry in the Pacific Northwest. Prepared for the Western Aluminum Producers, Portland, Oregon.

Arthur D. Little, Inc. 1979a. A Survey of Potential Processes for the Manufacture of A luminum, Prepared for Argonne Nationa 1 Laboratory. ANL /OEPM-79-4. Argonne, II Iino is.

Arthur D. Little, Inc. 1979b. Environmental Considerations of Selected Energy Conserving Manufacturing Process Options: Volume VIII. "Alumina/Aluminum Industry Report." EPA-600/7-76-034h, Industrial Environmental Research Lab, Cincinnati, Ohio.

Beck, Theodore R. 1977. Fina1 Report on Improvements in Energy Efficiency in Industrial Electrochemical Processes, for Argonne Nationa 1 Laboratory, ANL /OEPM-77-2. Argonne, I17ino is.

Boercker, S. W. July 1978. Energy Use in the Production of Primary Aluminum. ORAU/I EA-78-14(M), prepared for the Department of Energy, Office of Policy and Evaluation by Oak Ridge Associated Universities, Oak Ridge, TN 37830.

Bonneville Power Administration, 1979 Allocations Policy Development Project, Discussion Papers . "Direct Service Industrial Customers." Portland, Oregon.

Bonneville Power Administration. July 30, 1979. "Numer ical Rate Analys is," Report No.96-272. To accompany S.885, Pac ific Northwest Power Planning and Conservation Act before the U.S. Senate, June 21, 1979.

Bonneville Power Administration. 1977. The Role of the Bonneville Power Administration in the Pacific Northwest Power Supply System, Appendix C, BPA Power Marketing. Draft Environmental Impact Statement, DOI/BPA, Portland, oregon.

Bonneville Power Administration. April 1980b. The Role of the Bonneville Power Administration in the Pac if ic Northwest Power Supply System. DOE/EIS0066 (Rev ised), Portland, Oregon.

Bonneville Power Administration. 1980a. 1979 Annual Report. DOE/BPA, Portland, Oregon.

Bosworth, Barry. 1976. "Capac ity Creation in Basic-Materials Industries," in Brookings Papers on Economic Activity, 2:1976. The Brookings Institute, Washington D.C.

Bosworth, Barry. 1978. "Memorandum to Senator Henry Jackson Concerning the Impact of BPA Rates on the Aluminum Industry. "Prepared by the Council on Wage and Price Stability, Washington D.C.

Ch, M Hi11. January 1977. Effect of Bonneville Power Administration Industrial Service on Pacific Northwest Power Costs. Prepared for the 
Bonneville Power Administration Industrial Customers Committee, by $\mathrm{Ch}_{2} \mathrm{MH} \mathrm{Hill}$, Seattle, Washington.

Charpie, R. A. and P. W. MacAvoy. 1978. "Conserving Energy in the Production of Aluminum." Resources and Energy . North-Holland Publishing Company, New

York, New York.

Ernst and Ernst. June 1976. The Energy-Economy Relationship. PB-255-171. Prepared for the Bonneville Power Administration. NTIS, Springfield, Virginia.

Hassoun, H. 1978. Industrial Energy Consumption Studies, Part I. The Aluminum Industry. Oregon Department of Energy, Salem, Oregon.

Industrial Customers of BPA, Ju1y, 1979. "Comments of BPA Direct-Service Industrial Customers Concerning PURPA Ratemaking Standareds." Portland, Oregon.

Industrial Customers of BPA, June, 1980. "Reply to GAO report EMD-80-71." Portland, Oregon.

Levy, Yvonne. Winter, 1980. "Pricing Federal Power in the Pacific Northwest: An Efficiency Approach," in San Fransisco Federal Reserve Bank-Economic Review Winter Quarter, 1980.

Skea, J. 1980. "Electricity Supplies for the Primary Aluminum Industry," in Resources Policy, March 1980.

Sparrow, F.T. and Coward H. 1980. "The Aluminum Process Model Documentation." Purdue University, Lafayette, Indiana.

U.S. Department of Commerce, Bureau of the Census. 1977 Census of Manufactures, Fuels and Electric Energy Consumed, Part 1. Industry Groups and Industries." MC77-SR-4, U.S. Government Printing Office, Washington D.C.

U.S. Department of Commerce, Office of Industrial Economics. 1979. The Pacific Northwest Aluminum Industry: The Impact of Anticipated Power Rate Increases to 1991. Prepared for the Bonneville Power Administration, Portland, Oregon.

U.S. Department of Energy, Office of Public Affairs. 1978. The National Energy Act. DOE, Washington D.C.

U.S. General Accounting Office. "Hypothetical Transfer of Construction Funds from Nuclear Powerplants to Electricity Conservation and Renewable Energies," (EMD-80-71). GAO, Washington, D.C.

Washington Public Interest Research Group (WPIRG). November 1978. The Future of the Aluminum Industry in the Pacific Northwest. University of Washington, Seattle, Washington. 


\section{DISTRIBUTION}

No. of

Copies

OFFSITE

A. A. Churm

U.S. Department of Energy

Chicago Patent Group

9800 South Cass Avenue

Argonne, IL 60438

27 U.S. Department of Energy

Technical Information Center

D. W. Arpi

Teknekron Research, Inc. 2118 Milvia Street

Berkeley, CA 94704

Mr. Bailet

Richard Barber Associates

1000 Connecticut Ave., N.W.

Suite \#707

Washington, DC 20036

S. Ba11ou

Argonne National Laboratory

9700 South Cass Avenue

Argonne, IL 60439

J. A. Coleman

Office of Environmental Assessments

Mai1 Stop EP-33, Germantown

U.S. Department of Energy

Washington, DC 20545

R. M. Davis

Oak Ridge National Laboratory

P.0. Box $X$

Oak Ridge, TN 37830

J. Emery

Bonneville Power Administration

P.0. Box 3621

Portland, OR 97208
No. of

Copies

T Esvelt

Bonneville Power Administration

P.0. Box 362.1

Portland, OR 97208

A. R. Evans

Argonne National Laboratory

9700 South Cass Avenue

Argonne, IL 60439

A. G. Fremling

Acting, Assistant Secretary

Environmenta 1 Protection, Safety, and Emergency Preparedness

U.S. Department of Energy

Washington, DC 20545

W. Fulkerson

Oak Ridge National Laboratory

P.O. Box $X$

Oak Ridge, TN 37830

R. W. Gillette

Industrial Customers of BPA

Suite 464, Lloyd Building

700 N.E. Multnomah Street

Portland, OR 97232

T. Harris

Office of Environmental Assessments

U.S. Department of Energy M/S EP-33

Washington, DC 20545

L. Harris

Industrial Customers of BPA

Suite 464, Lloyd Building

700 N.E Multnomah Street

Portland, OR 97232 
No. of

No. of

Copies

Copies

P. W. House

W. E. Siri

Office of Environmental Assessments

Lawrence Berkeley Laboratory

U.S. Department of Energy (M/S E-201)

Washington, DC 20545

University of $\mathrm{Cal}$ ifornia

Berkeley, CA 94720

R. K. Lohrding

Los Alamos Scientific Laboratory

E. R. WI lliams

Regulatory Analysis Division

University of $\mathrm{Ca}$ lifornia

P.0. Box 1663

Los Alamos, NM 87545

P. M. Meier

Building 475

Brookhaven National Laboratory

Associated Universities, Inc.

Upton, NY 11973

D. M. Monti

Technology Assessments Division

U.S. Department of Energy (M/S E-201.)

Washington, DC 20545

\section{ONSITE}

DOE-RICHLAND OPERATIONS

H. E. Ransom

BATTELLE-HUMAN AFFAIRS RESEARCH CENTERS

U.S. Department of Energy M/S EP-33

B. Louzin-Library Services/HARC

Washington, DC 20545

2 T. S. Needels

Technology Assessments Division

U.S. Department of Energy M/S EP-33

Washington, DC 20545

PACIFIC NORTHWEST LABORATORY

E. Redman

Preston, Thorgrimson, Ellis, \& Holman 2000 IBM Building

Seattle, WA 98101

W. J. Bair

D. L. Hessel (10)

W. J. Hopp

A. L. Kretz (5)

Economics Library (5)

Publishing Coordination (2)

Technical Information Files (5) KE

E. Reich

Merril Lynch, Pierce, Fenner and

Smith, Inc.

One Liberty Plaza

New York, NY 10080

A. Rudo 1ph

Battelle Memorial Institute

$500 \mathrm{King}$ Avenue

Columbus, $\mathrm{OH} 43201$

R. D. Shu 11

Regional Impacts Division

U.S. Department of Energy (M/S E-201)

Washington, DC 20545 